\title{
IS SOCIAL MEDIA CHALLENGING THE AUTHORITY OF THE JUDICIARY? RETHINKING THE EFFECTIVENESS OF ANONYMISED AND SUPER INJUNCTIONS IN THE AGE OF THE INTERNET
}

\author{
Thaddeus Manu, Lecturer \\ t.manu@herts.ac.uk \\ Felipe Romero Moreno, PhD., Lecturer \\ f.romero-moreno@herts.ac.uk
}

University of Hertfordshire, School of Law, Criminology and Political Science: De

Havilland Campus, Hatfield. AL10 9EU. United Kingdom

(Received August 2016; Accepted November 2016)

\begin{abstract}
While freedom of expression has a long and well-established constitutional foundation as a self-governing concept, the right to privacy is a relatively recent norm in the constitutional orientation of the United Kingdom. Until the Human Rights Act 1998, the right to privacy had little standing constitutionally. Following on from this standard-setting, notably, both rights have taken on added importance in our modern technological society. Nevertheless, the formulation of privacy into a legal doctrine of human rights seems to have presented a fundamental tension in relation to freedom of expression. As a matter of legal logic, the courts, through a consideration of the law, examine the substantive legal issues in terms of a balancing process, whereby the interest in privacy is balanced against the interest in freedom of expression. It is a matter of broad principle for the courts to rely on injunctions as ancillary instruments of equity in doing justice in this field. Significantly, while the elementary norm of an injunction is that it commands an act that the court regards as an essential constituent to justice, unfortunately, many contend that judges have gone beyond this point, and this is shifting opinions. In fact, serious concerns have been frequently expressed about the extent to which the rich are easily able to invoke the discretion of the court to grant injunctions in a fashion that remains an antithesis to the principle of open justice and also undermines the exercise of freedom of speech. While this suspicion is not entirely new to matters of procedural law, the recent case, PJS v News Group Newspapers turned on this controversy. Therefore, the aim of this paper is to examine the complexity of celebrity privacy injunctions in the age of the internet and question its relevance, as we outline the extent to which social media is challenging the authority of the state (judiciary) in this direction.
\end{abstract}

Keywords: Courts, Freedom of Speech, Human Rights, Injunctions, Privacy, Social Media.

\section{Introduction}

International human right instruments, particularly the European Convention of Human Rights (ECHRs), ${ }^{1}$ incorporate two competing rights - the right to privacy contained in Article 8 and the right to freedom of expression included in Article 10. 


\section{JOURNAL OF LEGAL STUDIES}

"Vasile Goldiș" Western University of Arad

Manu, T., Moreno, F.R. (2016)

Is Social Media Challenging the Authority of the Judiciary? Rethinking the Effectiveness of Anonymised and Super Injunctions in the Age of the Internet

The former is often exercised by the press. ${ }^{2}$ As a non-self-executing treaty, which normally becomes judicially enforceable through the implementation of legislation, the ECHR was codified into the Human Rights Act (HRA) $1998 .^{3}$ Subject to the proportionality principle and other lawful restrictions Article 8 of the HRA provides that, 'Everyone has the right to respect for his or her private and family life, home and correspondence'. 4

It must be noted that the right to privacy has developed recently out of the need of a technological civilisation. Moreover, at the EU level, the right to privacy includes both privacy (Article 7 of the EU Charter) and protection of personal data (Article 8 of the EU Charter). ${ }^{5}$ This right finds its authentic expression within the system of individual rights. ${ }^{6}$ It has been reasoned that the right to respect for private life comprises more than one notion, but includes among other things - 'unwanted access to private information and unwanted access to [or intrusion into] one's ... personal space'. ${ }^{7}$ Within this essence, an individual may apply to the courts to seek a remedy to prevent or stop the publication of any material relating to their private life. $^{8}$

In a similar vein, Article 10 of the HRA stipulates that, 'Everyone has the right to freedom of expression'. Moreover, at the EU level, the right to freedom of expression is included in Article 11 of the Charter. ${ }^{9}$ This right shall include freedom to hold opinions and to receive and impart information and ideas without interference, and regardless of any major frontiers. As a matter of debate, the general policy of Parliament suggests that Article 10 of the HRA right may only be qualified in narrowly limited circumstances, subject to certain lawful limitations. ${ }^{10}$ Those circumstances include national security, public safety, the protection of morals, and the protection of the reputation or rights of others. ${ }^{11}$

Notably, the freedom of the press has an ancient lineage. ${ }^{12}$ The jurisprudence of courts even maintains that freedom of expression constitutes one of the essential foundations of a democratic society. ${ }^{13}$ Without it, many civilised states believe that democracy would be no more than a "sham". ${ }^{14}$ There are of course manifest dangers in any undertaking that aims to subdue the freedom of the press. This freedom has long been defended, and the courts emphasised the importance of freedom of expression or speech long before the enactment of the HRA. ${ }^{15}$ It remains besides the point, however, that much of the private sexual conduct of a celebrity might interest the public and help sell newspapers. ${ }^{16}$ This viewpoint is non-negotiable. The matter is well put by Lord Lester: 'News is a business and not only a profession. Commercial pressures push papers to publish salacious gossip and invasive stories' ${ }^{17}$

Unfortunately, as an unintended fashionable consequence, we can see clearly that Article 10 of the HRA contrasts sharply with the exercise of the Article 8 right alluded to in the framework of the ECHR. ${ }^{18}$ Importantly, both are now vital 
Manu, T., Moreno, F.R. (2016)

Is Social Media Challenging the Authority of the Judiciary? Rethinking the Effectiveness of Anonymised and Super Injunctions in the Age of the Internet

features of our democratic system despite the fact that Britain's proud tradition of a free press is in conflict with the right to privacy. The general expectation however, is that some compromise between them must be made. ${ }^{19}$ Nevertheless, structuring that compromise entails some difficulties and dangers. ${ }^{20}$ Such issues can only be properly considered and resolved by judges in individual cases before the courts. This is where equity would generally play a key role. Still, while equity has become a settled system, one central concern follows that in the exercise of judicial discretion, some judges have used injunctions ruthlessly and unjustly. ${ }^{21}$

Importantly, injunctions are one of the most popular equitable remedies. They provide a very good tool for the judiciary to accommodate often conflicting interests in order to do justice between the parties. ${ }^{22}$ In fact, injunctions as a matter of equitable remedy are discretionary and are decided on established principles after careful balancing of the rights of the respective parties. ${ }^{23}$ This means that as a matter of legal principle the courts exercise their power to grant an injunctive relief judiciously, and only when necessity, just and proportionality exist. ${ }^{24}$ Until the decision of the House of Lords in American Cyanimid Co. v Ethicon Ltd, ${ }^{25}$ it was generally considered as a matter of legal threshold that an applicant for interlocutory relief had to show a strong prima facie case. ${ }^{26}$

Now, the principle established as an ordinary common law approach is that, if there is a serious issue to be tried and the judge thinks that the balance of convenience so requires, an injunction should be granted. ${ }^{27}$ From the perspective of legal logic, Section 12 of the HRA is the starting point for drawing on the notion of any balancing exercise. ${ }^{28}$ Theoretically, and as a matter of legal construction, the threshold test in Section 12(3) of the HRA, which applies to an application to restrain prior publication, was whether the applicant had established a real prospect of success at trial, rather than that success was more likely than not. ${ }^{29}$ It provides that special regard is to be had to the right of freedom of expression in any case where it is in issue, and the public interest in disclosure of material that has journalistic, literary or artistic merit is to be considered. ${ }^{30}$ With its high threshold test, the Parliamentary draftsman intended that Section 12 would in principle protect freedom of speech. ${ }^{31}$

While this idea is clear from a jurisprudential position, since to the inception of the HRA into the UK legal landscape, there has been an increasing use of injunctions as a remedy for the protection of the right to privacy. ${ }^{32}$ Although injunctions have always been part of our jurisprudence, the feature that transforms an interim injunction into a super-injunction and anonymised injunctions are a recent development. ${ }^{33}$ Despite traditionally being the creature of the judiciary, and by the Civil Procedure Rules (CPR) 39.2(4), ${ }^{34}$ disproportionate use could undermine the principle of open justice. ${ }^{35}$ Super-injunctions, as stated, sincerely and in some respects carry the "nomenclature of novelty". ${ }^{36}$ As a form of interim injunction, a 


\section{JOURNAL OF LEGAL STUDIES}

"Vasile Goldiș" Western University of Arad

Manu, T., Moreno, F.R. (2016)

Is Social Media Challenging the Authority of the Judiciary? Rethinking the Effectiveness of Anonymised and Super Injunctions in the Age of the Internet

super-injunction not only binds those against whom it is issued, but also any third parties who have notice of the injunction, under what is known as the "Spycatcher principle". ${ }^{37}$

Third parties served with copies of such an injunction are, under this principle, subject to the court's contempt jurisdiction, the aim of which is to protect the court's process against any acts and words tending to obstruct the administration of justice, which is a matter of equity. ${ }^{38}$ While a super-injunction is in force, breach of its terms, either by those against whom it is issued, or by third parties with notice of it, is an interference with the proper administration of justice and a contempt of court, which may result in committal, the imposition of a fine or the sequestration of property. ${ }^{39}$ That said, an application for an anonymised or super-injunction is one to which the principle of open justice applies. An anonymised injunction is an interim injunction that restrains a person from publishing information that concerns the applicant and is said to be confidential or private where the names of either or both of the parties to the proceedings are not stated. ${ }^{40}$

Until recently the term super-injunction was unknown to the law of England and Wales. ${ }^{41}$ Super-injunctions and anonymised injunctions can be analysed as a species of anonymity order and a form of privacy order, as well as a species of non-disclosure, or anti-tipping-off order. ${ }^{42}$ Significantly, and more broadly, the common thesis is that the courts have given too much weight to Article 8 on the protection of legally enforceable rights to privacy and confidentiality, and insufficient weight to freedom of speech under Article $10{ }^{43}$ In other words, the suspicion is that the courts are literally banning the press from exercising their Article 10 right unfairly and unreasonably. ${ }^{44}$

While this tension is not entirely new to matters of procedural law, the recent case, PJS v News Group Newspapers Ltd has attracted much attention and the Supreme Court even recognises this controversial development. ${ }^{45}$ This case has turned on the old opposing debate between the two competing rights, and has succeeded in pushing it further into relatively uncharted territory in the legal discourse. Pending hearing at the time of writing, the scope of PJS is relevant in our analysis, ${ }^{46}$ as the Supreme Court even concedes in its decision that some may still question whether the case merits the weight of legal attention. ${ }^{47}$ Notably, as per the Supreme Court's decision, the media in England and Wales are literally barred from naming PJS, notwithstanding the fact that the celebrity at the centre of this injunction has been named on social media and in several other jurisdictions. ${ }^{48}$

In fact, this is the basis on which the News Group Newspapers applied to have the injunction set aside on grounds of "some significant change of circumstances" ${ }^{49}$ In other words, the protected information had entered the public domain. ${ }^{50}$ As Tugendhat J. once reasoned: "it is obvious that if the purpose of this injunction were to preserve a secret, it would have failed in its purpose'. ${ }^{51}$ The court of appeal 
Manu, T., Moreno, F.R. (2016)

Is Social Media Challenging the Authority of the Judiciary? Rethinking the Effectiveness of Anonymised and Super Injunctions in the Age of the Internet

granted the application even though in the earlier judgment Jackson LJ. decided that there was no public interest in the story being published. ${ }^{52}$ By a majority of 4 to 1 , with Lord Toulson dissenting, ${ }^{53}$ the Supreme Court decided that the Court of Appeal had made an error in its legal reasoning, ${ }^{54}$ since it had incorrectly given greater weight to the right of freedom of expression than to the competing right to privacy. ${ }^{55}$

Working through the Court of Appeal's decision, the Supreme Court stated that the former had wrongly stated that the right to freedom of expression deserved greater weight in principle, including the availability of the information. ${ }^{56}$ The Supreme Court emphasised that neither right has a preference in principle over the other and that an appropriate balancing act should be undertaken by the Court to establish whether the rights of the proposed publisher or the party wishing to restrain use of their private information should prevail, and this is generally a matter of judicial principles established by a considerable number of authorities at the highest level. ${ }^{57}$ The Supreme Court noted that while Jackson LJ gave an impressive and careful judgment, he misdirected himself in an important respect when reaching the decision to discharge the interim injunction ${ }^{58}$ Importantly, the court took a much more sceptical approach, stating that if Parliament takes the view that the courts have not adapted the law to fit current realities, then, of course, it can change the law, for instance by amending Section 12 of the HRA ${ }^{59}$ Moreover, they settled that the Court of Appeal had been mistaken in referring to it as having "limited public interest", and in its introduction of that supposed interest into a balancing exercise, ${ }^{60}$ when in fact, there was none at all in the case. ${ }^{61}$

This confounds every legal logic, as the Supreme Court is defying the gravity of modern reality, based on the factual notion that the injunction is no longer effective, and lacking any force of law, thinking that the publication of the story in newspapers in the US, Canada, and even in Scotland would not be sufficient in itself to undermine the claim for an enduring injunction on the ground of privacy. ${ }^{62}$ As the Supreme Court puts it, 'An English court has little control over what foreign newspapers and magazines may publish', ${ }^{63}$ admitting that 'the internet and social networking have a life of their own' ${ }^{64}$ The contrast here is the more primitive view that the Supreme Court's decision is a walking contradiction of the power of social media and this convinces very few, even the judges, as to the effectiveness of injunctions in a situation where the information injuncted is already in the public domain. ${ }^{65}$

In addition to being compliant with the necessity and proportionality principles, the injunction must also be "appropriate", that is to say, it must be compliant with the appropriateness principle. This means that an injunction that is unable to achieve its aim, or that is clearly ineffective in achieving it - as would be the case here cannot be deemed appropriate, necessary or proportionate. This development is 


\section{JOURNAL OF LEGAL STUDIES}

"Vasile Goldiș" Western University of Arad

Manu, T., Moreno, F.R. (2016)

Is Social Media Challenging the Authority of the Judiciary? Rethinking the Effectiveness of Anonymised and Super Injunctions in the Age of the Internet

troubling for the reason that celebrity injunctions may be irrelevant, as the jurisdictional reach of the courts in England and Wales is weakened considerably given that social media is ramping up its crusade against the judiciary by highlighting their displeasure to gagging orders.

We therefore follow the Supreme Court's lead that their decision in PJS will probably give rise to further, entirely legitimate, debate on the value of such injunctions in the age of the internet. ${ }^{66}$ Therefore, the aim of this paper is to examine the complexity of celebrity privacy injunctions and question its relevance, as we outline the extent to which social media is challenging the authority of the state (judiciary) in this direction.

\section{The Evolution of Privacy and Freedom of Expression as Concepts}

Privacy is a sweeping concept that has gathered legal momentum recently. ${ }^{67}$ Privacy follows the theory of the natural rights argument. ${ }^{68}$ In their famous 1890 Harvard Law Review article, Samuel Warren and Louis Brandeis provided a sensible analysis and evolutionary justification for the right to privacy. ${ }^{69}$ They supplemented natural rights theory with positive law arguments, and concluded that there is a strong enough basis for finding a right to privacy in the common law. $^{70}$

The development of the law was inevitable. The intense intellectual and emotional life, and the heightening of sensations that came with the advance of civilisation, made it clear to men that only a part of the pain, pleasure and profit of life lay in physical things. ${ }^{71}$ Thoughts, emotions and sensations demanded legal recognition, and the common law enabled judges to afford the requisite protection, without the interposition of the legislature. ${ }^{72}$ This reinforced the central thesis advanced by Samuel Warren and Louis Brandeis that common law is not static but undergoes continuing growth as culture develops. As they put it: 'Political, social, and economic changes entail the recognition of new rights, and the common law, in its eternal youth grows to meet the demands of society. ${ }^{73}$

This followed a recognition that the press was overstepping in every direction the obvious bounds of propriety and decency. Gossip is no longer the resource of the idle, and to satisfy a prurient taste the details of sexual relations, which can only be procured by intrusion upon the domestic circle, are broadcast in the columns of the daily papers. ${ }^{74}$ Prosser's account typifies this point. He, in principle, contends that the right to privacy resulted from the 'growing abuses of the press and this made a remedy upon such a distinct ground essential to the protection of private individuals against the outrageous and unjustifiable infliction of mental distress'. ${ }^{75}$ Despite its well-founded legislative possibilities, it is unsurprising, therefore, that the theoretical foundations of the right of privacy are relatively unformed and, indeed, are the subject of much current controversy. ${ }^{76}$ Philosophers, legal theorists 
Manu, T., Moreno, F.R. (2016)

Is Social Media Challenging the Authority of the Judiciary? Rethinking the Effectiveness of Anonymised and Super Injunctions in the Age of the Internet

and jurists have spent a great deal of time lamenting the great difficulty in reaching a satisfying conception of privacy. ${ }^{77}$ The widespread discontent over conceptualising privacy persists even though the concern over privacy has escalated into an essential issue for freedom and democracy. ${ }^{78}$ It has been noted that 'even the most strenuous advocate of a right to privacy must confess that there are serious problems of defining the essence and scope of this right'. ${ }^{79}$

The difficulty in articulating what privacy is and why it is important has often made privacy law ineffective and blind to the larger purposes it must serve. ${ }^{80} \mathrm{In}$ strict theory, privacy enables individuals to formulate ideas without public scrutiny; it allows people to remove their "public masks" and act differently in private; and it enables them to form intimate relationships, including the freedom to choose with whom they share their private thoughts. ${ }^{81}$ Essentially, it is aimed to support the individual, to protect the core of individuality in relation to the collective society. ${ }^{82}$

Paradoxically, a categorical description of the right to privacy was precisely what Cooley first wrote in 1888 , that privacy is the "right to be let alone". ${ }^{83}$ It is rooted in the dignity of the individual human being, and the respect that is therefore due to the private sphere or space that belongs to the individual. ${ }^{84}$ In other words, the purpose of establishing a right of privacy is to protect certain areas of individual autonomy, ${ }^{85}$ identity and intimacy from any intrusion by society at large. ${ }^{86}$ Thus, the right to privacy is clearly a vital element in any system of individual rights, ${ }^{87}$ and has important consequences in preserving human dignity. ${ }^{88}$

Nevertheless, these brief formulations demonstrate how elusive the concept can be, as even judges have called for separate legislation on privacy. ${ }^{89}$ Even if we agree on these outlines of a value structure, it must be admitted that we are still some distance from having a definite, workable and independent substantive legislation on privacy. ${ }^{90}$ This is true, as advocates often fail to supply a unified theory that can serve as a foundation for the development of a comprehensive privacy law. ${ }^{91}$

An understanding of the functions of privacy illuminates a further problem, as a strict approach to enforcing the right to privacy will not do justice to freedom of speech as an independent right, ${ }^{92}$ although, the courts in principle, have for years had a good idea that privacy ought to be given adequate legal protection. ${ }^{93}$ It would therefore appear self-evident that the statutory right to privacy should operate to prevent any state institution from undermining this fundamental liberty, including the press obtaining certain types of information about the private affairs of a person. $^{94}$

This approach would seem to follow from the very nature of the right to privacy protection for the individual against all forms of collective pressure, ${ }^{95}$ except that English law historically recognised no right to privacy per $s e,{ }^{96}$ but rather a breach of confidence. ${ }^{97}$ The absence of a right to privacy was in 1991 confirmed by the 


\section{JOURNAL OF LEGAL STUDIES}

"Vasile Goldiș" Western University of Arad

Manu, T., Moreno, F.R. (2016)

Is Social Media Challenging the Authority of the Judiciary? Rethinking the Effectiveness of Anonymised and Super Injunctions in the Age of the Internet

Court of Appeal in Kaye $\mathrm{v}$ Robertson, which reasoned that the "monstrous invasion of privacy" ${ }^{\prime 98}$ of the claimant did not entitle him to any relief in English law. ${ }^{99}$ Lord Hoffmann later confirmed the same proposition. ${ }^{100}$ In reality, and with varying scope and function, several statutes protect privacy in particular situations. ${ }^{101} \mathrm{~A}$ general right to privacy was for the first time imported into English jurisprudence via the HRA $1998 .^{102}$

The basis for this development was that the autonomy, identity and intimacies of the individual have been put under greater strain by irresponsible journalism. ${ }^{103}$ The dangers to privacy have been exacerbated not only by the vast increase in information assembled but by the availability of that information through modern social networks. ${ }^{104}$ With this thinking, the courts have consistently taken the position that private information has no social value and they would almost certainly conclude that such information was not something that the public needed to know. ${ }^{105}$ However, the argument of John Mill challenges this foregoing thought. He maintains that even expression that is false has social importance, in that it evokes response, stimulates rethinking and otherwise stirs debate. ${ }^{106}$ The claim is that anything that is published is by definition "newsworthy" and a "matter of public interest. ${ }^{107}$

Along the same vein as privacy, the constitutional foundations for a free press are solidly established. ${ }^{108}$ Never has it been more true that information is power. ${ }^{109}$ In some common law jurisdictions, the press has a right expressed as constitutional right and the courts have interpreted it as such. ${ }^{110}$ Its origins stem from the abandonment of the English censorship laws at the end of the seventeenth century. ${ }^{111}$ Press freedom is one of the most fought over rights in the history of mankind. Freedom of expression is essential for discovering new truths and thus enabling social progress. It allows for the moral and cultural self-development of individuals; and it is necessary for the flourishing of a healthy democracy. ${ }^{12}$

Like privacy its values are rooted in the fundamental structure of our democratic culture. It has developed and is reflected in both our way of life and our laws. ${ }^{113}$ It is evident from the conceptual underpinnings deducted from the well-established legislative history that on a scale involving a balancing process freedom of speech would tilt the right to privacy over. ${ }^{114}$ This follows the normative view that the vitality of the democratic process itself rests upon citizens having access to information. ${ }^{115}$ And the citizenry must depend in large measure upon the capacity of the press to discover this information and to disseminate it to the public. ${ }^{116}$

\section{The Complex Task of Finding a Balance Between Articles 8 and 10}

The laws around privacy already have a statutory foundation - with equal footing as the freedom of expression. The courts have not sought to give precedence to either article but rather have interpreted Articles 8 and 10 of the HRA as being 
Manu, T., Moreno, F.R. (2016)

Is Social Media Challenging the Authority of the Judiciary? Rethinking the Effectiveness of Anonymised and Super Injunctions in the Age of the Internet

rights of equal standing. ${ }^{117}$ Before delving into analytical issues, in 2001 Lord Nicholls acknowledged the presumed tension between the interaction of the two fundamental rights. ${ }^{118}$ Drawing various strands of case law together, we see that judicial opinions often take the approach based on the subjective expectation of privacy. ${ }^{119}$ The House of Lords decision in Campbell v MGN Ltd is a good starting point. ${ }^{120}$

There is now a two-stage test for determining cases where an infringement of the right to privacy is alleged. ${ }^{121}$ The first element enjoins the court to take a logical approach in looking at whether a person has a "reasonable expectation of privacy" in the sense that it is protected by Article 8 - taking into consideration all the circumstances of the case. ${ }^{122}$ Thus, the "reasonable expectation of privacy" test has been confirmed as the guiding test. ${ }^{123}$ If that is not so then the claimant's case fails. ${ }^{124}$ Once a reasonable expectation of privacy is established, the court must consider the second stage, commonly referred to as the "balancing exercise".

In other words, if there is a reasonable expectation of privacy, the court balances the Article 8 rights of the claimant against the defendant's Article 10 rights. ${ }^{125}$ Lord Steyn set out the approach:

First, neither article has as such precedence over the other. Secondly, where the values under the two articles are in conflict, an intense focus on the comparative importance of the specific rights being claimed in the individual case is necessary. Thirdly, the justifications for interfering with or restricting each right must be taken into account. Finally, the proportionality test must be applied to each. For convenience I will call this the ultimate balancing test. ${ }^{126}$

Under this approach, the court evaluates whether it is necessary in any given case to qualify one right in order to protect the other. ${ }^{127}$ There are different degrees of privacy; the more intimate the aspect of private life that is engaged, the more serious the reasons must be for interference. ${ }^{128}$ They will take into account many factors in attributing relative weight to the competing claims. Relevant to the balancing exercise are the level of detail and the format of the publication and the value accorded by the individual to the privacy of the material. ${ }^{129}$ When these factors are entered into a balancing test, the probability is that they will clearly produce more favourable results, from the standpoint of the right of privacy, than would otherwise be the case if the information concerned the health and sexuality of the individual. ${ }^{130}$ This is generally the reasoned legal position.

However, this stance also faces another difficulty underlined by the technicality of the public interest principle often invoked by the press. Here, we see that the worst excesses of the balance that the courts ought to find is affected by the operational requirements of the public interest, which is sometimes too elastic in terms of legal logic. Defining the public interest is not conceptually easy in relation to privacy. ${ }^{131}$ The general policy of Parliament is that the public interest principle around privacy 


\section{JOURNAL OF LEGAL STUDIES}

"Vasile Goldiș" Western University of Arad

Manu, T., Moreno, F.R. (2016)

Is Social Media Challenging the Authority of the Judiciary? Rethinking the Effectiveness of Anonymised and Super Injunctions in the Age of the Internet

already has a legislative foundation, and therefore, Parliament failed to recommend a statutory definition of the notion of public interest, and is best taken by the courts in privacy cases. ${ }^{132}$ The theory of the public interest is mentioned in a number of statutes, including ones concerning privacy. ${ }^{133}$

Thus, if a public interest can be demonstrated in the revelation of private information, that will often lead to the courts striking the balance in favour of freedom of expression in that case. ${ }^{134}$ This is also the position adopted by the European Court of Human Rights. ${ }^{135}$ As gossip in newspapers can help sales and thus enable journalism to continue to perform its essential role in a democracy, it might follow that the commercial viability of the press should be a factor when balancing the public interest in a story against an individual's right to privacy. ${ }^{136}$ Thus, if newspapers did not exist, issues of public interests would be undermined. This is a line of reasoning that has been acknowledged in some cases. Baroness Hale of Richmond reiterated that, 'one reason why press freedom is so important is that we need newspapers to sell in order to ensure that we still have newspapers at all'. ${ }^{137}$

In the narrative, Parliament agrees that the media play a vital role in furthering public debate, exposing wrongdoing and enhancing democracy. ${ }^{138}$ In an inverse assumption, the Rt Hon. Lord Woolf stated that, 'the courts must not ignore the fact that if newspapers do not publish information which the public are interested in, there will be fewer newspapers published, which will not be in the public interest'. ${ }^{139}$ However, in McKennitt v Ash, the Court of Appeal held that Lord Woolf's statements in A v B plc. cannot be reconciled with the decision of the European Court of Human Rights in the first Von Hannover v Germany ${ }^{140}$ and so 'cannot be read as any sort of binding authority on the content of Articles 8 and $10{ }^{141}$ Importantly, one instrument that the courts have in weighing the balance of these two competing rights is injunction.

\section{Equitable Remedies and the General Principles Governing the Granting of Injunctions}

All writers on the subject of equity, regardless of their philosophical persuasion, agree that the term "equity" is difficult to define, and the loose use of the term to mean fundamental fairness, has resulted in decisions by equity courts whose rationale remains hidden when "equity" is offered as the reason for the decision. ${ }^{142}$ The legal realists refer to injunctions as a quintessential equitable remedy in the administration of justice. ${ }^{143}$ It is simply a court order prohibiting a person from taking a particular action or requiring them to take a particular action. The interim injunction is one type of injunction that is relevant in this analysis.

This is simply the imposition of a temporary judicial stay pending full trial. ${ }^{144}$ This, it achieves maintaining the status quo prior to trial and judgment, thereby enabling 
Manu, T., Moreno, F.R. (2016)

Is Social Media Challenging the Authority of the Judiciary? Rethinking the Effectiveness of Anonymised and Super Injunctions in the Age of the Internet

the effective enforcement of substantive rights to take place after the trial. ${ }^{145} \mathrm{In}$ other words, by their nature, interim injunctions are a separate action within a larger claim, but they can be essential in circumstances where a party wishes to preserve the status quo until the dispute has been resolved with a view to facilitating the administration of justice at the trial. ${ }^{146}$

Interim injunctions are an important remedy in privacy actions. They are a judicial norm that follows the conceptual logic that once information is public, its private nature cannot be restored; it is not possible to undo a breach of privacy. ${ }^{147}$ Preventing a story appearing in the first place will usually be more important to a claimant than obtaining damages after the event. ${ }^{148}$ The situation can be contrasted with defamation, where injunctions are virtually impossible to obtain, ${ }^{149}$ unless, where a claimant's reputation may be vindicated by an award of damages. ${ }^{150}$ Importantly, the rules of injunctions, like the rules of equity generally, were a product of the institution of the Court of Chancery. ${ }^{151}$

Near the end of the thirteenth century, the equity in the common law courts began to decline. ${ }^{152}$ The courts were becoming too rigid, technical and overly formal, as they focused more often on the strict letter of the law, and less on equitable considerations. ${ }^{153}$ Equity originated in a society where authority counted more than democracy, and where the wishes of the powerful counted more than sound explanations for judicial action. ${ }^{154}$ Subsequently, this instrument has been a central part of the common law for generations, and naturally there exists some tension between the two regimes: law ensures strict uniformity and predictability, while equity tempers law to offer relief from hardship. ${ }^{155}$

Equity is powerful and traditionally supplements the common law. In this broad sense, equity means the power to adapt the relief to the circumstances of the particular case, "individualised justice", in effect. ${ }^{156}$ That is, where harm is threatened, injunctions would come to be used in equity. ${ }^{157}$ It moderates the rigid and uniform application of law by incorporating standards of fairness and reasonableness into the judicial process ${ }^{158}$ upon which all legal decisions must be based. ${ }^{159}$

In other words, where the application of the common law would have operated too harshly equity will take precedence over the common law, and this is predominantly done to achieve what is sometimes referred to as natural justice, or more simply speaking, fairness. ${ }^{160}$ Equity came into the legal landscape to correct the substantive and procedural deficiencies seen in common law. ${ }^{161}$ An expansive equity practice developed as a necessary companion to common law; ${ }^{162}$ although they were complementary, law and equity courts each had a distinct procedural system, jurisprudence and outlook. ${ }^{163}$ In a broad jurisprudential sense, equity means the power to do justice in a particular case by exercising discretion to 


\section{JOURNAL OF LEGAL STUDIES}

"Vasile Goldiș" Western University of Arad

Manu, T., Moreno, F.R. (2016)

Is Social Media Challenging the Authority of the Judiciary? Rethinking the Effectiveness of Anonymised and Super Injunctions in the Age of the Internet

mitigate the rigidity of strict legal rules. Thus, justice is the hallmark of equity. This is the fundamental principle on which equity sits.

Notwithstanding this, an interim injunctive relief is not a remedy that is liberally granted, and a court will always consider any hardship that the parties will sustain due to the granting of or refusal to grant such a remedy. ${ }^{164}$ For the greater part of the nineteenth and twentieth centuries, applicants for interim injunctions had to meet the test laid out in Beecham Group Ltd v Bristol Laboratories Pty Ltd. The first is whether the plaintiff has made out a prima facie case, in the sense that if the evidence remains as it is there is a probability that at the trial of the action the plaintiff will be held entitled to relief. Importantly, the second inquiry is whether the inconvenience or injury which the plaintiff would be likely to suffer if an injunction were refused outweighs or outweighed by the injury which the defendant would suffer if an injunction were granted. ${ }^{165}$

The requirement enunciated above attracted William Williamson Kerr attention in 1888, who in his so-called "A Treatise on the Law and Practice of Injunctions" argued that 'The Court must, before disturbing any man's legal right, or stripping him of any of the rights with which the law has clothed him, be satisfied that the probability is in favour of his case ultimately failing in the final issue of the suit'. ${ }^{166}$ That threshold test was altered by the House of Lords in the seminal case of American Cyanamid Co. v. Ethicon Ltd. ${ }^{167}$

One of the overarching principles engendered to determine whether an interim injunction is an appropriate and permissible remedy is the likelihood of irreparable harm to the claimant in the absence of an injunction. ${ }^{168}$ Lord Diplock placed these overarching principles into the substantive guidelines for establishing whether an applicant has an adequate case for the granting of an interim injunction. ${ }^{169} \mathrm{In}$ applying the broad principles set out in the American Cyanamid case, the court is enjoined to consider whether there is a serious issue to be tried, whether damages would be an adequate remedy, where the balance of convenience lies, and any other special factors.

\section{Discretion in the Context of Equity under Section 12 of the Human Rights} Act

The notion of an injunction as equitable relief is discretionary, and that discretion is commonly exercised by the High Court in the light of all of the circumstances of the case. ${ }^{170}$ The term "discretion" when used in the context of equitable relief means "principled discretion". ${ }^{171}$ It is a sound judicial discretion that is governed by the settled rules of equity. ${ }^{172}$ In addition to the exclusive and auxiliary jurisdictions of equity to order injunctions, the courts were granted discretion via the conduits of a statutory enactment in the Judicature Act 1873 for that purpose. For the sake of legal certainty, Section 25(8) provided that: 
Manu, T., Moreno, F.R. (2016)

Is Social Media Challenging the Authority of the Judiciary? Rethinking the Effectiveness of Anonymised and Super Injunctions in the Age of the Internet

An injunction may be granted or a receiver appointed by an interlocutory order of the court in all cases in which it shall appear to the court to be just or convenient that such order should be made; and any such order may be made either unconditionally or upon such terms and conditions as the court thinks just. ${ }^{173}$

While many would applaud equity for its flexibility to award individualised justice, it is also the case that no system of jurisprudence can escape completely the curse of discretion, as the exercise of good intentions in equity will not generally guarantee an equitable result. ${ }^{174}$ Simply put, a legal system of open-ended discretion with no standards is an open invitation for judges to reach decisions based on nothing more than their attitudes, predilections and biases, without analysis and the constraints of legal rules and principles. ${ }^{175}$

There were concerns during the passage of the Human Rights Bill 1997-1998 regarding how the courts might interpret the right to privacy without further guidance. ${ }^{176}$ There was unease about the effect on the media if injunctions were too readily obtainable, leading to the media not pursuing stories that may be in the public interest for fear of having to defend an injunction issued on them. Notably, in the House of Lords the then chairman of the Press Complaints Commission, the Rt Hon Lord Wakeham, moved an amendment that aimed 'to stop the development of a common law of privacy'. ${ }^{177}$ This move was instantly attacked. Replying to the debate on it, the Lord Chancellor, the Rt Hon Lord Irvine of Lairg, said:

I repeat my view that any privacy law developed by the judges will be a better law after incorporation of the convention because the judges will have to balance and have regard to articles 10 and 8, giving article 10 its due high value. What I have said is in accord with European jurisprudence. ${ }^{178}$

\section{The Normative Principle Behind Section 12 of the Human Rights Act}

In response to the fierce debate Parliament introduced Section 12 of the HRA. ${ }^{179}$ Section 12(3) requires the courts to grant interim injunctions only when 'satisfied that the applicant is likely to establish that publication should not be allowed'. ${ }^{180}$ That is a higher threshold and the courts are technically freed from the fetter by the House of Lord's decision in American Cyanamid's case, where the court must be satisfied that the claim 'is not frivolous or vexatious; in other words, that there is a serious question to be tried'. ${ }^{181}$ The courts have interpreted this as meaning that the applicant will usually have to demonstrate that they are "more likely than not" to succeed at trial. ${ }^{182}$ Guidance on the application of Section 12(3) is set out in Cream Holdings Ltd v Banerjee. ${ }^{183}$

This guidance is further reinforced by the Master of the Rolls' committee, which sought to tighten up the procedures for granting anonymised and super-injunctions, by ensuring that they were granted only when strictly necessary, and recommending that a Practice Guidance be issued on the approach to them. ${ }^{184}$ The 


\section{JOURNAL OF LEGAL STUDIES}

"Vasile Goldiș" Western University of Arad

Manu, T., Moreno, F.R. (2016)

Is Social Media Challenging the Authority of the Judiciary? Rethinking the Effectiveness of Anonymised and Super Injunctions in the Age of the Internet

legal background against which Section 12 of the HRA has to be interpreted is empirically familiar. In the 1960s the approach adopted by the courts to the granting of interim injunctions was that the applicant had to establish a prima facie case. ${ }^{185}$ The judge had to establish this before questions about the so-called "balance of convenience" were considered. A prima facie case was understood, at least in the Chancery Division, as meaning that the applicant must establish that as the evidence currently stood on the balance of probability he would succeed at the trial. ${ }^{186}$

Under its purposive reading from the Parliamentary draftsman perspective, one could conceive that Section 12(4) of the HRA was thought to make clear that freedom of expression should normally take precedence over the right to privacy. ${ }^{187}$ Recalling the debate during the introduction of the Section 12 amendment in 19971998, this understanding becomes clear. Jack Straw MP argued in the House of Commons that 'it is intended overall to ensure ex parte injunctions are granted only in exceptional circumstances. Even where both parties are represented, we expect that injunctions will continue to be rare, as they are at present'. ${ }^{188}$

Significantly, as a matter of empirical logic, Parliament has adopted a report that has tended to produce a conclusion that is the opposite to the foregoing understanding. Parliament maintains that it does not think that the provisions of Section 12(4) of the HRA do not require the courts to 'have particular regard to the importance of the Convention right to freedom of expression' when considering whether to grant any relief, meaning that Article 10 has precedence over Article $8{ }^{189}$ This is a stark deviation from the concerns raised during the Parliamentary debate on the Human Rights Bill 1997-1998. ${ }^{190}$ The concerns have morphed into operational difficulties and we are somehow witnessing that the application of Section 12 is without controversy, as the interpretation adopted by the courts fails to achieve the purpose underlying its validity.

The thinking is that the courts are undermining the essential requirements of Section 12 of the HRA, and have been too willing to grant injunctions, especially anonymised or super-injunctions, or had granted them in the wrong circumstances - directly impacting on media coverage of issues of legitimate public interest. ${ }^{191}$ Admittedly, under English law exceptions are allowed. CPR 39.2(3)(g) states that a hearing may be in private if the court considers that this is necessary in the interests of justice.

Other sub-rules list the following situations as justifying curbs on publicity: where publicity would defeat the object of the hearing; where the hearing involves matters relating to national security; where it involves confidential information that may be harmed by publicity; where it is necessary to protect the interests of a child or a protected party; or where an application is made without notice and it would be unjust to any respondent for there to be a public hearing. Finally, CPR 39.2(4) 
Manu, T., Moreno, F.R. (2016)

Is Social Media Challenging the Authority of the Judiciary? Rethinking the Effectiveness of Anonymised and Super Injunctions in the Age of the Internet

states that the court may order that the identity of any party or witness must not be disclosed if it considers this necessary in order to protect the interests of that party or witness.

\section{The Principle of Open Justice and the Issue of Anonymised and Super- injunctions}

As these foregoing procedural provisions show, there are circumstances in which publicity may be cut down. However, they also suggest that some degree of transparency must be maintained because the exceptions mentioned in the rules envisage only limited or partial derogation from publicity. ${ }^{192}$ This is where the doctrine of open justice builds up a coherent and transparent body of principles that the court must follow. The proper approach to anonymisation has been clarified by the Court of Appeal. ${ }^{193}$ The trend towards anonymisation has been deprecated by the Court of Appeal in the context of interim injunctions in proceedings to protect private information. ${ }^{194}$

A sceptical viewpoint is that both super-injunctions and anonymised injunctions represent a new extension of established forms of anonymity, privacy and nondisclosure orders developed beyond their previous historical limits, as the currency of these judicial instruments appears to harm the just operation of the doctrine of open justice. ${ }^{195}$ The most popular claim is that the term "equity" is often misunderstood and, as a consequence, often misapplied by courts when they are asked to grant an equitable remedy such as injunctions. ${ }^{196}$ To this end, many who believe in the doctrine of "rough justice" think that judges are misusing injunctions and producing rough justice. To put this in a proper context, there is always the question regarding "the balance of the risk of doing an injustice". ${ }^{197}$ Lord Hoffmann puts it as follows:

The principal dilemma about the grant of interlocutory injunctions, whether prohibitory or mandatory, is that there is by definition a risk that the court may make the 'wrong' decision, in the sense of granting an injunction to a party who fails to establish his right at the trial (or would fail if there was a trial) or alternatively, in failing to grant an injunction to a party who succeeds (or would succeed) at trial. ${ }^{198}$

In the recent past, super-injunctions and anonymised injunctions have been more widely used than is strictly necessary. They are a controversial development, owing to the extent to which they depart from open justice. They are divisive for another reason, namely that they are the most obvious form of the recent development of the substantive law of privacy as a consequence of the enactment of the HRA. ${ }^{199}$ As Lord Rodger observed, this mechanism, which was properly only exceptional, has become "a widespread phenomenon". ${ }^{200}$ Moreover, Lord Woolf MR took this further when he once said: 'The need to be vigilant arises from the natural tendency 


\section{JOURNAL OF LEGAL STUDIES}

"Vasile Goldiș" Western University of Arad

Manu, T., Moreno, F.R. (2016)

Is Social Media Challenging the Authority of the Judiciary? Rethinking the Effectiveness of Anonymised and Super Injunctions in the Age of the Internet

for the general principle to be eroded and for exceptions to grow...? ${ }^{201}$ Additionally, Professor Zuckerman notes: 'What the English administration of justice has not allowed is for the entire legal process to be conducted out of the public view and for its very existence to be kept permanently secret under pain of contempt'.202

Following this primary disagreement that super-injunctions and anonymised injunctions impact on open justice and are an affront to fundamental fairness, the Attorney General on 23 May 2011, announced to the House of Commons that a joint committee would be established to consider the operation of the law concerning privacy and injunctions. ${ }^{203}$ This move follows the concern about the erosion of the principle of open justice, which is a long-established and fundamental aspect of our justice system and of any liberal democracy committed to the rule of law. As a general proposition, the operation of the default mechanism of justice demands that hearings are carried out in public. ${ }^{204}$

8. The Empirical Significance of the Principle of Open Justice in the Judiciary

Besides equity, common law also supports the doctrine of open justice. Thus, it has been a central principle of the common law system since its origins that justice is conducted, and judgments are given, in public. ${ }^{205}$ The cardinal importance of open justice is demonstrated by the provisions of Article 6 of the European Convention on Human Rights. ${ }^{206}$ This principle is, as Lord Shaw described it 'a sound and very sacred part of the constitution of the country and the administration of justice. . $\therefore{ }^{207}$ Open justice is of constitutional importance because it is 'on the whole, the best security for the pure, impartial, and efficient administration of justice, the best means for winning for it public confidence and respect' ${ }^{208}$ To give the notion of open justice a statutory backing Section 67 of the Senior Courts Act 1981 states: 'Business in the High Court shall be heard and disposed of in open court except in so far as it may, under this or any other Act, under rules of court or in accordance with the practice of the court, be dealt with in chambers'. ${ }^{209}$

The empirical significance of the open justice norm is that it is not only an aspect of freedom of speech but rather it is also an aspect of the principle that justice is both done and seen to be done. ${ }^{210}$ Similarly, it has been held that it is a centrally important way of ensuring that the court fulfils its constitutional duty of ensuring that justice is done. ${ }^{211} \mathrm{~A}$ strong point in favour of this theory is that it supports the rule of law in a democratic society. ${ }^{212}$ The European Court of Human Rights has similarly recognised the publicity of court proceedings as fundamental for the protection of litigants from the abuse of procedural rights, which, in conditions of secrecy, may go unchecked. ${ }^{213}$

With a similar disposition, Professor Zuckerman maintains that transparency of court proceedings reduces the scope for ill-informed and malicious criticism of

54 DE GRUYTER Journal of legal studies Volume 18 Issue 32/2016

OPEN $\quad$ ISSN 2457-9017; Online ISSN 2392-7054. Web: publicatii.uvvg.ro/index.php/jls. Pages 39-87 
Manu, T., Moreno, F.R. (2016)

Is Social Media Challenging the Authority of the Judiciary? Rethinking the Effectiveness of Anonymised and Super Injunctions in the Age of the Internet

judicial decisions, thereby protecting the judiciary itself from obloquy. ${ }^{214}$ While we do no seek to run down the value of the judicial system, it is also the case that super-injunctions and anonymity orders may run the risk of unintentionally encouraging suspicion and gossip in relation to innocent third parties. ${ }^{215}$ Indeed, there is credibility in the point that such speculation could be even more damaging than if no injunction were to be granted at all. ${ }^{216}$ By bringing in the moral, social and legal issues, open justice promotes public debate, which is so important to the democratic shaping of the law. ${ }^{217}$ This can promote confidence, and that can only be maintained and thrive where the administration of justice is transparent, comprehensible and accountable. ${ }^{218}$

Importantly, while the principle of open justice is a fundamental constitutional principle, it is not an absolute principle. ${ }^{219}$ Super-injunctions and anonymity orders can only ever be exceptional and can only be justified on grounds of strict necessity. ${ }^{220}$ Parliament takes the position that departures from the principle of open justice should be exceptional and should only happen when they are essential. ${ }^{221}$ This position is enhanced by the fact that derogations from the general principle can only be justified in exceptional circumstances, ${ }^{222}$ when they are strictly necessary as measures to secure the proper administration of justice. ${ }^{223}$ That is, general principles can never be used habitually. ${ }^{224}$

The basis for any claimed restriction ultimately rests on a judicial assessment, and the judge must first be satisfied that the facts and circumstances of the case are sufficiently strong to justify encroaching on the open justice rule. ${ }^{225}$ As already stated, derogations should, where justified, be no more than strictly necessary to achieve their purpose. The general rule is that the court is not exercising a "wide discretion" when deciding to grant derogations made under CPR 39.2(3)(g), or under any other part of CPR 39(2). ${ }^{226}$ A point made is that it is a "matter of obligation" if it is justified once the court has applied the relevant test. ${ }^{227}$

\section{Social Media in the Age of the Internet}

Social media are a recent invention. The development of the internet has helped propel social media as an open platform shared by all. The two most popular social networking sites, Facebook and Twitter, were founded in 2004 and 2006 respectively. They may be relatively new, but they are certainly big. 1.2 billion people regularly use Facebook, and 34 million of them are in the UK; 255 million regularly use Twitter, and 15 million of them are in the UK. ${ }^{228}$ In addition to these well-known providers, there are many other social media forums, based all over the globe, with different focuses of activity including LinkedIn; YouTube; WhatsApp; Snapchat; Instagram and Pinterest - all with the purpose of "social networking", of connectivity - enabling people to express themselves and interact using the internet. ${ }^{229}$ Taken together, these social media platforms are likely to contain 


\section{JOURNAL OF LEGAL STUDIES}

"Vasile Goldiș" Western University of Arad

Manu, T., Moreno, F.R. (2016)

Is Social Media Challenging the Authority of the Judiciary? Rethinking the Effectiveness of Anonymised and Super Injunctions in the Age of the Internet

hundreds of millions of communications every day. For example, there are 500 million "tweets" a day. ${ }^{230}$

New media have greatly increased the range and availability of information sources; in addition, technological developments have allowed citizens to become "publishers". ${ }^{231}$ That is, "the Internet has now become one of the principal means by which individuals exercise their right to freedom of expression and information, providing as it does essential tools for participation in activities and discussions concerning political issues and issues of general interest' ${ }^{232}$ Consequently, anyone can make his or her views known to the world, or can break their own news.

Additionally, in the light of its 'accessibility and its capacity to store and communicate vast amounts of information, the Internet plays an important role in enhancing the public's access to news and facilitating the dissemination of information in general'. ${ }^{233}$ This has obvious benefits for freedom of expression the role of Twitter in fostering the exchange of ideas and the organisational capability that led to the Arab Spring, for example, is widely documented. ${ }^{234}$ The internet allows those who have competing views to give effect to them, and to publish information that would not ordinarily be published in traditional media. ${ }^{235}$ The Court's Grand Chamber confirmed the understanding that 'user-generated expressive activity on the Internet provides an unprecedented platform for the exercise of freedom of expression.... ${ }^{236}$ Importantly, along the same line of reasoning, the French Constitutional Council has affirmed that 'in the current state of means of communication and given the generalised development of public online communication services and the importance of the latter for the participation in democracy and the expression of ideas and opinions, this right (to freedom of expression) implies freedom to access such services'. ${ }^{237}$

As the AG noted in the European Court of Justice (ECJ) case of Google v Spain (C-131/12) 'the internet has revolutionised our lives by removing technical and institutional barriers to dissemination and reception of information... These benefit consumers, undertakings and society at large ${ }^{238}$ Moreover, in the same decision the AG explained that: 'The internet magnifies and facilitates in an unprecedented manner the dissemination of information'.

Confirming the empirical logic, it was similarly contended that, as 'the invention of printing in the 15th century enabled reproduction of an unlimited number of copies that previously needed to be written by hand, uploading of material on to the internet enables mass access to information which earlier could perhaps only be found after painstaking searches, and at limited physical locations. Further explanation of the revolutionary nature of the internet is that 'Universal access to information on the internet is possible everywhere, with the exception of those countries where the authorities have limited, by various technical means (such as 
Manu, T., Moreno, F.R. (2016)

Is Social Media Challenging the Authority of the Judiciary? Rethinking the Effectiveness of Anonymised and Super Injunctions in the Age of the Internet

electronic firewalls), access to the internet or where the access to telecommunications is controlled or scarce'. ${ }^{239}$

\section{The Law of Contempt in the Age of the Internet}

Equity acts in personam, they say. That is, courts of equity have coercive powers to hold a violator in contempt through contempt proceedings where his actions are in breach of any judicial order tending to interfere with the course of justice. ${ }^{240}$ Several statutory provisions explicitly prohibit the disclosure of injuncted information. Importantly, Section 2 of the Contempt Act 1981 identifies that the publication of a story can impede or prejudice injunctions. This is well-grounded in law and within the purview of CPR Part 81 also supported by Practice Direction $81{ }^{241}$ Section 1 of the Malicious Communications Act 1988, ${ }^{242}$ and Section 127 of the Communications Act $2003^{243}$ also hint that such disclosure or comments on injuncted information creates the potential that a very large number of cases could be prosecuted before the courts.

The notion of strict liability applies to contempt. However, under normal circumstances, a person is not guilty of contempt unless he can be charged with knowledge of the injunction. ${ }^{244}$ Contempt follows the principle of quasi-criminal proceedings. Lord Hoffmann has a clear view on this. It is inherent in his opinion that: "The only means available to the court to enforce its order is the quasicriminal procedure of punishment for contempt' ${ }^{245}$ It is entirely appropriate that as a consequence of committal for contempt of the court the obligation to be specifically enforced be sufficiently certain and precise so as to make the defendant's duty, in complying with the order, clear.

Notably, injunctions, where appropriately granted, are necessary to protect individual privacy; indeed, they are often the only means of protecting it. ${ }^{246}$ If injunctions are to provide adequate protection, it is essential that there are no avoidable barriers to their enforcement. However, the test of equitable jurisdiction has long been whether the law courts can provide "plain, adequate and complete" relief. ${ }^{247}$ Implicit in the notion of an injunction is something that predominantly involves 'a judicial process operating in personam, and requiring the person to whom it is directed to do or refrain from doing a particular thing, ${ }^{248}$ This is important, as the expanding role of equity in the broader administration of justice pursuant to injunctions has always been controversial and questioned. ${ }^{249}$

It has been suggested that the single most effective measure for enforcing an injunction that had been widely flouted would be for the Attorney General to bring an action for contempt. ${ }^{250}$ That is, the Attorney General in his role as "guardian of the public interest" can bring proceedings for contempt of court. ${ }^{251}$ To do this, the Director of Public Prosecutions (DPP) has also published guidelines for the application of the current statute law to prosecutions involving social media 
Manu, T., Moreno, F.R. (2016)

Is Social Media Challenging the Authority of the Judiciary? Rethinking the Effectiveness of Anonymised and Super Injunctions in the Age of the Internet

communications. ${ }^{252}$ However, the question is whether the notion of public interest demands that the Attorney General spends public funds to enforce contempt arising originally and directly from civil litigation. ${ }^{253}$ Parliament does not share this view and has adopted a contrary position in principle. It maintains that:

The Attorney General should be more willing to exercise his power as Guardian of the Public Interest to bring actions for civil contempt of court in respect of breaches of injunctions online. The threshold for him intervening should be lower. Such action would provide a strong deterrent against future such breaches. ${ }^{254}$

\section{The Difficulty of Enforcing Injunctions in the Age of the Internet}

Court orders and statutory prohibitions can apply to those communicating via social media in the same way as they apply to others. Accordingly, any communication via social media that may breach a court order or a statutory prohibition should be considered under the relevant legislation. ${ }^{255}$ The DPP's guidelines provide that prosecutors should make an initial assessment of the content of the communication and the conduct in question so as to bring proceedings. ${ }^{256}$

Lord Advocate Frank Mulholland, in examining whether messages posted on social media should be treated as a crime, said the test was simple: 'If it would be illegal to say it on the street, it is illegal to say it online' ${ }^{257}$ However, the Lord Advocate may have forgotten the herculean task of enforcing injunctions in the age of the internet. The DPP acknowledges this difficulty. In fact, Section 3 of the Contempt Act 1981 provides an absolute defence of innocent publication or distribution. It stipulates that:

A person is not guilty of contempt of court under the strict liability rule as the publisher of any matter to which that rule applies if at the time of publication (having taken all reasonable care) he does not know and has no reason to suspect that relevant proceedings are active. (2) A person is not guilty of contempt of court under the strict liability rule as the distributor of a publication containing any such matter if at the time of distribution (having taken all reasonable care) he does not know that it contains such matter and has no reason to suspect that it is likely to do so.

Moreover, according to the DPP's guidelines, there is the potential for a chilling effect on free speech and prosecutors should exercise considerable caution before bringing charges under Section 1 of the Malicious Communications Act 1988 and Section 127 of the Communications Act 2003. The caution proceeds from the standpoint that since both provisions will often engage Article 10 of the European Convention on Human Rights, prosecutors are reminded that these provisions must be interpreted consistently with the free speech principles in Article 10. 
Manu, T., Moreno, F.R. (2016)

Is Social Media Challenging the Authority of the Judiciary? Rethinking the Effectiveness of Anonymised and Super Injunctions in the Age of the Internet

Accordingly, the DPP retreats from this position by maintaining that no prosecution should be brought under Section 1 of the Malicious Communications Act 1988 or Section 127 of the Communications Act 2003 unless it can be shown on its own facts and merits to be both necessary and proportionate. ${ }^{258} \mathrm{~A}$ prosecution is unlikely to be both necessary and proportionate where the content of the communication did not obviously go beyond what could conceivably be tolerable or acceptable in an open and diverse society that upholds and respects freedom of expression. ${ }^{259}$

Consequently, the DPP then reminds prosecutors that the mere fact that words were irritating, contentious, unwelcome and provocative is not enough to justify the invocation of the criminal law unless they tended to provoke violence. ${ }^{260}$ In a similar vein, in Dehal v CPS, Moses J, referring to Section 4A of the Public Order Act 1986, held that: '.. the criminal law should not be invoked unless and until it is established that the conduct which is the subject of the charge amounts to such a threat to public order as to require the invocation of the criminal as opposed to the civil law'. ${ }^{261}$ There is a high threshold that must be satisfied before the evidential stage in the Code for Crown Prosecutors is met. ${ }^{262}$

Furthermore, at a more practical level, in terms of the injunction's effectiveness, court orders and statutory prohibitions could in principle oblige that social networking sites such as, Facebook or Twitter had in place a number of technical solutions designed to prevent users from bypassing the injunction. Firstly, these sites might be required to adopt a notice-and-takedown system whereby anyone could notify the operators of such platforms of user comments which are supposedly in breach of the injunction by bringing it to the operators' attention.

Secondly, another technical solution may be, for instance, the adoption of an automatic word-based filtering measure designed to block Facebook's comments and tweets. Practically speaking, this filtering software looks for key words that have previously been added to a list of forbidden words and then once a forbidden word is detected such a word is filtered out and blocked. However, the practical aspect of this technology is suspect, not to mention it legal shrewdness. Notably, as filtering software cannot appropriately differentiate between illegal and legal content thereby leading to the blocking of legitimate speech (over-blocking), in the copyright context this technology was deemed unlawful by the CJEU in the cases of SABAM v Scarlet (C 70-10) and SABAM v Netlog (C 360-10).

At this point, we could add that whatever technical solution that is used in order to make the injunction as effective as possible, under Articles 8, and 10 of the ECHR, such a measure must be compatible with the ECtHR three-part non-cumulative test. In others words, firstly, the adoption of the injunction must be 'in accordance with the law'; secondly, it must pursue one or more legitimate aims included in Articles 
Manu, T., Moreno, F.R. (2016)

Is Social Media Challenging the Authority of the Judiciary? Rethinking the Effectiveness of Anonymised and Super Injunctions in the Age of the Internet

8 and 10 ECHRs; and finally, it must be 'adequate', 'necessary' and 'proportionate' to achieve those aims.

\section{Jurisdictional Limit of the Courts in the Age of the Internet}

It is well-established that the court's jurisdiction to grant injunctive relief is without limit, and (can) be exercised either in support of any legal right, or in the creation of a new equitable right, as the court (thinks) fit in the application of equitable principles. ${ }^{263}$ Jurisdiction rests either on the inherent authority of the court or the statutory conferral of powers to aid the operation of the courts in terms of fairness and the protection of justified expectations.

The normative principle underpinning procedural law teaches us that the High courts have exclusive jurisdiction. This position charts the conventional wisdom that the judiciary everywhere has the authority to apply some laws extraterritorially to enforce foreign judgments. ${ }^{264}$ In fact, there seems to already be an adequate legal foundation in state practice, and scholarly consensus on this is strong, except that the question of jurisdiction has always been one of intrigue to both lawyers and even the general public. Morgan's case is one of the earliest cases on the enforcement of foreign rulings pursuant to equity. ${ }^{265}$ Moreover, Houlditch v. Marquis of Donegal confirmed the possibility of enforcement of foreign judgments as a principle of equity. ${ }^{266}$

Giving its reasoning, in Houlditch v. Marquis, the House of Lords stressed that the Court of Chancery had jurisdiction to enforce foreign judgments because it could examine whether the judgments were rightly made. ${ }^{267}$ The basis for this jurisdiction is sound and straightforward in theory. Its analytical approach carefully follows the legal principle of comity of nations. ${ }^{268}$ Ulrich Huber was one of the first to use the comity of nations to explain why it was appropriate for a sovereign nation to enforce a foreign judgement. ${ }^{269}$

This doctrine was meant to repair the incorrect but widely shared conceptual view that a judgement is valid only within the territorial boundaries of the court in which it was rendered. ${ }^{270}$ Despite the lack of academic agreement as to whether comity of nations is a rule of law at all, ${ }^{271}$ the argument underpinning the principle of comity of nations generally proceeds according to the classical doctrine of what is generically known as "legal obligation". Traditionally, this is a judicially created doctrine of English law, which says that if a legal obligation is created by a foreign court in a competent jurisdiction it is proper that the judgement must be enforced and obeyed everywhere. ${ }^{272}$

From the English jurisprudence perspective, comity only affirms our confidence that there is an obligation to obey the law. ${ }^{273}$ The liberal interpretation of the principle sustaining the doctrine of legal obligation is stated nowhere better than in the following words of Lord Blackburn, who observed in Godard v Gray that the

60 DE GRUYTER Journal of legal studies Volume 18 Issue 32/2016

OPEN $\quad$ ISSN 2457-9017; Online ISSN 2392-7054. Web: publicatii.uvvg.ro/index.php/jls. Pages 39-87 
Manu, T., Moreno, F.R. (2016)

Is Social Media Challenging the Authority of the Judiciary? Rethinking the Effectiveness of Anonymised and Super Injunctions in the Age of the Internet

principle of the law of nations dictates that 'a state is bound to enforce within its territories the judgment of a foreign tribunal'. ${ }^{274}$ In other words, from the moment a judgement is issued and a legal obligation is created, it must be enforced everywhere.

The first evidence outside England and Wales of this legal doctrine is found in Russell v Smyth. ${ }^{275}$ A US court first adduced the comity of nations as the theoretical basis for recognition of a foreign judgement in Guyot v Hilton. ${ }^{276}$ In its logical deduction, while the foregoing principle would provide a fluid approach to judicial integrity, two principled questions would operate to render the application of the doctrine of legal obligations and comity of nations in enforcing foreign rulings highly redundant.

The first concerns the question of conflict of laws; and the second concerns the court's own initiative to willingly exercise jurisdiction over foreign judgements. ${ }^{277}$ From a practical perspective, these two preceding questions are inherently connected. Upon the basis of the second, the assumption will generally maintain its hold that as a general rule laws have no effect or force beyond the borders of the sovereignty from which their authority derives. ${ }^{278}$ That is, international law limits a country's authority to exercise jurisdiction in cases that involve interests or activities of non-residents. ${ }^{279}$

From the perspective of legal pluralism, it is clear that in the age of the Internet the court's jurisdiction over the enforcement of a foreign judgement is premised on wishful thinking, as there can be practical difficulties in asserting some degree of certainty in this area. In the main, these difficulties are due to the crossjurisdictional nature of the Internet, as well as the capacity for anonymous posting from internet service providers that do not easily identify their end-user. ${ }^{280}$ As one author has recently put it:

The Internet's challenge to traditional concepts of jurisdiction and governance is multifaceted, but really boils down to two factors. First when you're online, you're both everywhere and nowhere at once. Ubiquity is perhaps the defining characteristics of this remarkable new "borderless" medium. There are no passports on the Internet; you travel freely from one destination to another at the click of a button. And geography is a remarkably meaningless concept for Internet denizens. . . Second, no single entity or country owns or controls the Internet. Persons of this so-called 'network of networks' are owned by private companies, organizations, or even governments, but it is impossible to point to any specific 'owner' of the Net writ large. ${ }^{281}$

The logical and legal bases of the notion of enforcement of foreign judgements raise one additional difficult question, as to whether such authority is a mere concession that the court makes on the grounds of convenience and utility, and not as the result of a binding obligation or duty to enforce foreign judgements. In fact, 


\section{JOURNAL OF LEGAL STUDIES}

"Vasile Goldiș" Western University of Arad

Manu, T., Moreno, F.R. (2016)

Is Social Media Challenging the Authority of the Judiciary? Rethinking the Effectiveness of Anonymised and Super Injunctions in the Age of the Internet

modern analysis of the existence of the equitable jurisdiction on foreign verdicts has not been perfectly persuasive in the academic literature, and even cases where the courts have contemplated the enforcement of foreign judgments have reached mixed results. ${ }^{282}$

At first glance, the case of Yahoo Inc. v. La Ligue Contre LeRacisme et L'Antisemitisme appears to have paved a new path in the terrain of legal issues concerning the internet. In the case a US federal district court for the Northern District of California held unenforceable an order of the French court that required a California-based Internet Service Provider (ISP), Yahoo Inc., to block French citizens' access to Nazi material displayed or offered for sale on the ISP's US website. ${ }^{283}$ At issue was whether it was consistent with the Constitution and laws of the US for another nation to regulate speech by a US resident within the US on the basis that such speech could be accessed by internet users in that nation. ${ }^{284}$ Scholars have noted that courts in the US are assumed to enforce foreign country injunctions so long as public policy is not offended and there is no undue burden on the American court. ${ }^{285}$

\section{The Global Nature of the Internet and the Weakness in the Courts' Enforcement Powers on Injunctions}

Today, the chorus of opinion is that the law of privacy has been ineffective, particularly in remedying the burgeoning collection, use and dissemination of personal information in the "Information Age". ${ }^{286}$ The global nature of the internet poses jurisdictional challenges, as much of the material accessed from the UK is published on servers hosted in foreign domains. The proliferation of online media outlets increases the possibility for injunctions to be breached, and offers the potential for injuncted information to be spread quickly around the world. ${ }^{287}$

The challenges posed to injunctions were demonstrated in May 2011 when the Giggs injunction was broken by at least one Twitter user and the information repeated as many as 75,000 times. ${ }^{288}$ The United Nations Human Rights Council acknowledges the conceptual difficulties in this area. It agrees that, 'Notably, encryption protects the content of communications but not identifying factors such as the Internet Protocol (IP) address, known as metadata. Third parties may gather significant information concerning an individual's identity through metadata analysis if the user does not employ anonymity tools' ${ }^{289}$

The immediate conclusion drawn by the Council is that "Anonymity is the condition of avoiding identification'. Providing further emphasis, the Council reasoned that 'A common human desire to protect one's identity from the crowd, anonymity may liberate a user to explore and impart ideas and opinions more than she would be using her actual identity'. ${ }^{290}$ It maintained that 'Individuals online may adopt pseudonyms (or, for instance, fake e-mail or social media accounts) to 
Manu, T., Moreno, F.R. (2016)

Is Social Media Challenging the Authority of the Judiciary? Rethinking the Effectiveness of Anonymised and Super Injunctions in the Age of the Internet

hide their identities, image, voice, location and so forth, but the privacy afforded through such pseudonyms is superficial and easily disturbed by Governments or others with the necessary expertise; in the absence of combinations of encryption and anonymizing tools, the digital traces that users leave behind render their identities easily discoverable'. ${ }^{291}$

The Council's analysis was very pragmatic. It notes that 'Users seeking to ensure full anonymity or mask their identity (such as hiding the original IP address) against State or criminal intrusion may use tools such as virtual private networks (VPNs), proxy services, anonymizing networks and software, and peer-to-peer networks'. In its conclusion, it found that 'One well-known anonymity tool, the Tor network, deploys more than 6,000 decentralized computer servers around the world to receive and relay data multiple times so as to hide identifying information about the end points, creating strong anonymity for its users'. ${ }^{292}$

Some UK-based bloggers prefer their blogs to be physically hosted in the US, in order to benefit from the First Amendment protections there. ${ }^{293}$ This is done in order to protect the blog against legal action in the UK, which, whilst still possible, becomes more difficult and expensive as a result of the overseas hosting. ${ }^{294}$ What seems to weaken this thinking further is the fact that the UK has three separate legal systems: those of England and Wales, Northern Ireland and Scotland. Section 18(5)(d) of the Civil Jurisdiction and Judgments Act $1982^{295}$ provides that an interim measure (including an injunction) obtained in one of the UK's jurisdictions is not enforceable in the other jurisdictions. ${ }^{296}$

This premise primarily supports the logical contention that in practice the jurisdiction of the court in enforcing injunctions faces enforcement difficulty in the age of the internet. Generally, any judgement obtained in the High Court in London is not enforceable in Scotland or Northern Ireland; separate orders would have to be obtained from those jurisdictions registered in specific courts, ${ }^{297}$ except a judgement entered under Lugano Convention. ${ }^{298}$ However, final injunctions granted in one jurisdiction in the UK can be enforced in the other jurisdictions, by virtue of that same Act. ${ }^{299}$

The Attorney General did not think there was a problem with cross-border enforcement with the UK; because separate legal systems are a fundamental part of the UK's national make-up, there was no way around the issue. ${ }^{300}$ Parliament also takes the view that interim injunctions granted in one jurisdiction in the UK are enforceable in the other two jurisdictions in the same way as final injunctions are. $^{301}$ This issue arose in the Ryan Giggs case, ${ }^{302}$ where in the absence of a Scottish interim injunction (an interdict) the claimant's identity was published in Scotland. ${ }^{303}$

The paper added in its editorial column, 'Today we identify the footballer whose name has been linked to a court super injunction by thousands of postings on 


\section{JOURNAL OF LEGAL STUDIES}

"Vasile Goldiș" Western University of Arad

Manu, T., Moreno, F.R. (2016)

Is Social Media Challenging the Authority of the Judiciary? Rethinking the Effectiveness of Anonymised and Super Injunctions in the Age of the Internet

Twitter. Why? Because we believe it is unsustainable that the law can be used to prevent newspapers from publishing information that readers can access on the internet at the click of a mouse'. ${ }^{304}$ The Sunday Herald also stated: 'We should point out immediately that we are not accusing the footballer concerned of any misdeed. Whether the allegations against him are true or not has no relevance to this debate. The issue is one of freedom of information and of a growing argument in favour of more restrictive privacy laws ${ }^{305}$ The editor of that newspaper said that they had not breached the interim injunction because it did not apply in Scotland. ${ }^{306}$ So, the question is how effective is contempt, as a coercive instrument of the judiciary to maintain reasonable public confidence in judicial decisions, which is a foundation of the justice system in the age of the internet. ${ }^{307}$ The unfettered space enjoyed by the media is further enhanced by essential provisions of the Contempt Act 1981, which provides a shield to the reporter, and eventually tilts this balance towards freedom of speech. Section 10 dubbed "Sources of information" stipulates that:

No court may require a person to disclose, nor is any person guilty of contempt of court for refusing to disclose, the source of information contained in a publication for which he is responsible, unless it be established to the satisfaction of the court that disclosure is necessary in the interests of justice or national security or for the prevention of disorder or crime. ${ }^{308}$

More importantly, another threat to celebrity privacy injunctions is the Bill of Rights $1689 .{ }^{309}$ Article 9 provides that 'the Freedom of Speech and Debates or Proceedings in Parliament ought not to be impeached or questioned in any Court or Place out of Parliament'. ${ }^{310}$ This is usually considered to be a fundamental feature of the constitution. It provides the "final legal, recognition" of the constitutional principle of legal immunity to parliamentarians. ${ }^{311}$ As a cornerstone of parliamentary privilege, ${ }^{312}$ this has customarily been described as the "exclusive cognisance of Parliament" ${ }^{313}$ Its principal purpose was stated clearly by Lord Browne-Wilkinson:

The plain meaning of Article 9, viewed against the historical background in which it was enacted, was to ensure that Members of Parliament were not subjected to any penalty, civil or criminal for what they said and were able, contrary to the previous assertions of the Stuart monarchy, to discuss what they, as opposed to the monarch, chose to discuss. ${ }^{314}$

The decision of R v Chaytor \& Others [2010] 3 WLR reinforced this objective. ${ }^{315}$ It follows that what is said or done within the walls of Parliament cannot be inquired into in a court of law. ${ }^{316}$ It is not excluded by the presence of malice or fraudulent purpose and where the statement appears to be untrue to the knowledge of the maker it cannot be made the foundation of civil or criminal proceedings in as much as the maker acts honestly and responsibly. ${ }^{317}$ Thus, Article 9 is wide and also 
Manu, T., Moreno, F.R. (2016)

Is Social Media Challenging the Authority of the Judiciary? Rethinking the Effectiveness of Anonymised and Super Injunctions in the Age of the Internet

absolute. ${ }^{318}$ The exact scope of it has been fully tested and its legitimacy is clear even from a European jurisprudence perspective. ${ }^{319}$

An attempt by the courts to go beyond the constitutional boundary delimited by Article 9, as interpreted by the courts, would be unconstitutional. ${ }^{320}$ The Liberal Democrat Member of Parliament, John Hemming, who during an urgent House of Commons question on privacy orders named Ryan Giggs as the footballer CTB, ${ }^{321}$ relied on the Article 9 parliamentary privilege in breaking the court order (super injunction). He said, 'Mr Speaker, with about 75,000 people having named Ryan Giggs it is obviously impracticable to imprison them all' ${ }^{32}$

Even after this point Justice Tugendhat, sitting at the High Court, defiantly ruled that the injunction was still valid and should not be lifted, arguing that 'this is not about secrecy, this is about intrusion'. ${ }^{323} \mathrm{He}$ added that even if the level of protection now offered was limited, it was still potentially worthwhile: 'If a court can stop one person or five people [from harassing the player] - not 50,000 - is there not something to be achieved?' ${ }^{324}$ Nevertheless, despite the intensity of the verdict to keep the status quo, the case refused to die until Justice Eady on 15 December 2011, accepted that, 'There is no longer any point in maintaining the anonymity'. ${ }^{325}$

The general immunity of the press is further enriched by the normative principle enshrined in Section 2 of the Parliamentary Papers Act $1840 .{ }^{326}$ This provision grants qualified privilege or immunity to individuals in civil or criminal proceedings who publish any extract from or abstract of parliamentary proceedings subject only to bona fide and without malice. ${ }^{327}$ This means that when a Parliamentarian - like John Hemming in the case of Ryan Giggs - triggers immunity under Article 9 of the Bill of Rights 1689 the media can report the story thereafter on account of the Parliamentarian. Nevertheless, it is an open question as to whether publication of any extract from or abstract of Hansard, which had the effect of frustrating a court order and was deliberately intended to do so, would be held to be in good faith and without malice. However, this question appears to be a settled idea.

The 1999 Joint Committee concluded that 'in such circumstances i.e., where an injunction barring publicity is in force reporting a matter divulged in parliamentary proceedings is strictly a contempt of court' ${ }^{328}$ However, the point is whether this report, although persuasive, applies to the print media alone. If not, the question that follows is whether it (the report) can operate to undermine Section 2 of the Parliamentary Papers Act 1840, which has a statutory force, and more importantly, whether in the age of the internet and its cross-border flow of information the courts are still willing to undermine their own authority by granting to celebrities' super-injunctions and anonymised injunctions where the story is visible via social media platforms. 


\section{Conclusion}

The right to privacy is, as a legal concept, a fairly recent invention, except that it has fast gained jurisprudential momentum. ${ }^{329}$ Notwithstanding this, Danielle Citron observes that the privacy laws have severe limitations in combatting internet harassment. ${ }^{330}$ The formulation of privacy into a legal doctrine of human rights seems to have presented a fundamental tension in relation to freedom of expression, which is much older and is a well defended right by the media. As a matter of jurisprudential principle, the courts, through a consideration of the law, examine the substantive legal issues in terms of a balancing process, whereby the interest in privacy is balanced against the interest in freedom of expression. It is also a matter of broad standard for the courts to rely on injunctions as ancillary instruments of equity in doing justice in this field.

Significantly, while the elementary norm of an injunction is that it commands an act that the court regards as an essential constituent to justice, unfortunately some contend that judges have gone beyond this point, and this has already shifted opinions. In fact, serious concerns have been expressed about the extent to which the rich are easily able to invoke the discretion of the court to grant injunctions in a fashion that is in stark contrast to the principle of open justice. Therefore, the practice and procedure governing injunctions have come under the spotlight of late in civil proceedings.

Implicit in this understanding is the fact that the internet has had far-reaching effects on individual privacy. ${ }^{331}$ The advancement of technology, which has tended to remove the traditional publisher's role of "gatekeeper", gives everyone, through new media, the opportunity to disseminate information, and to express their views. ${ }^{332}$ However, the hallmarks of digital information and the ease of informational exchange facilitated by this medium lead to more noxious privacy and personality harms than ever before. ${ }^{333}$ Within this view, most commentators from the pro-media fraternity submit that mainstream newspapers are invariably served with the terms of injunctions granted against newspapers, ${ }^{334}$ as media coverage has highlighted the apparent inequity of laws being applied to print and broadcast media, which, cannot be enforced in the same way against those publishing online.

While this suspicion and tension is not entirely new to matters of procedural law, the recent case, PJS v News Group Newspapers has turned on this controversy. Even writers with a social bent can easily spot that there cannot be a proper rule of law without an effective judicial system that is capable of enforcing not just rights but also decisions using its coercive powers. In other words, the effectiveness of the judicial system as the final guarantor of rights crucially depends on the extent to which its decisions are enforced. In terms of the injunction's effectiveness, it is 
Manu, T., Moreno, F.R. (2016)

Is Social Media Challenging the Authority of the Judiciary? Rethinking the Effectiveness of Anonymised and Super Injunctions in the Age of the Internet

unlikely that there will ever be a foolproof technical solution able to prevent circumventing the effects of this particular type of injunctive relief. Yet, to a great extent, the development of the general rule of extraterritorial application of injunctions is dictated by reality and necessity.

Depending on which philosophical spectrum one sits, most writers would agree that cross-border transactions on social media have the tendency to complicate things simply due to the fact that pursuant to injunctions, the jurisdiction of the court is weakened. The current approach appears careless and unsustainable and undermines the authority of the judiciary, which has long remained the most revered state institution. Therefore, the main conclusion to be drawn from this paper is that since these injunctions cannot be considered able to achieve their aim, or put differently, are clearly ineffective in achieving them, it is arguable that they cannot be considered appropriate, necessary or proportionate, so they may be illegitimate.

Thus, perhaps the time has come for the government to acknowledge that 'it is absurd to hold back the flow of information in the digital age by using a court order that can only go as far as Hadrian's Wall' ${ }^{335}$ On the contrary, the violation of users' freedom of expression by the government, will be routine, disproportionate and illegal and this could potentially open up the door to a new era of legal challenges in the UK. However, no matter how sophisticated the injunctions granted, opposition from users will eventually lead to strategies to bypass their effectiveness being deployed and improved for instance, by using anonymity tools such as virtual private networks, proxy services or Tor.

\section{Reference}

1. A v. the United Kingdom [2003] 36 EHHR 51.

2. A Treatise on the Law and Practice of Injunctions (Philadelphia, Blackstone, 3rd ed. 1889)

3. Aday, S., Farrell, H., Lynch, M., Sides J., and Freelon, D., "New Media and Conflict After the Arab Spring" (Washington DC. United States Institute of Peace, Peaceworks No. 80. Blogs and Bullets II, 2012).

4. Abril, P. S., "A (My)Space of One's Own: On Privacy and Online Social Networks" (2007) 6 Northwestern Journal of Technology and Intellectual Property 1, 73.

5. Ahmet Yildirim v Turkey (ECHR 548, No.3111/10, 2012).

6. AMM v HXW [2010] EWHC 2457 (QB).

7. American Cyanimid Co. v Ethicon Ltd [1957] AC 396.

8. Attorney General v Leveller Magazine [1979] A.C. 440.

9. Attorney-General v Guardian Newspapers Ltd (No.2) [1990] 1 A.C. 109.

a. Attorney-General v Newspaper Publishing Plc [1988] Ch 333.

10. Attorney-General v Punch Ltd \& Another [2003] 1 A.C. 1046.

11. Axen v Germany (A/72) (1984) 6 E.H.R.R. 195.

12. A-G v Leveller. [A-G v Leveller Magazine Ltd [1979] A.C. 440. 
Manu, T., Moreno, F.R. (2016)

Is Social Media Challenging the Authority of the Judiciary? Rethinking the Effectiveness of Anonymised and Super Injunctions in the Age of the Internet

13. Beecham Group Ltd v Bristol Laboratories Pty Ltd (1968) 118 CLR 618.

14. Bender, P., Privacies of Life (New York, Harper's Magazine, April 1974).

15. Bender, P., Emerson, T., Haber, D., Dorsen, N., and Neuborne, B., Political and Civil Rights in the United States (Vol. 1, Fourth Edn. Little, Brown and Company; 1976).

16. Bernstein v. Skyviews Ltd. [1978] Q.B. 479.

17. Beaney, W., "The Right to Privacy and American Law" (1966) 31 Law and Contemporary Problems 2, 253.

18. Black's Law Dictionary (ed.) Bryan Garner (Thomson West; 10th Edition, 2014).

19. Black's Law Dictionary (West Publishing Co., Rev. 5th ed. 1979).

20. Bloustein, E., "Privacy as an Aspect of Human Dignity: An Answer to Dean Prosser" (1964) 39 The New York University Law Review 962.

21. Bonnard v Perryman [1891] 2 Ch 269.

a. Bradlaugh v Gossett (1884) 12 QBD 271.

22. Branzburg v. Hayes, 408 U.S. 665 (1972).

23. Buchanan v Jennings (Attorney General of New Zealand intervening) [2005] 1 AC 115.

24. Busuttil, G., Free Speech v Privacy - The Big Debate, Preventing Publication of Private Information - When you can and when can cannot (London, Sweet \& Maxwell, 2009).

25. Campbell, C., "The Court of Equity-A Theory of its Jurisdiction" (1903) 15 Green Bag 108.

26. Cayne-v- Global Natural Resources Plc [1984] 1 All ER 225.

27. Chanel Ltd v F W Woolworth \& Co Ltd [1985] 1 WLR 485.

28. Charter of Fundamental Rights of the European Union (Official Journal of the European Communities, 2000/C 364/01, 18.12.2000. 261 U.N.T.S. 140).

29. Chroust, AH., The "Common Good" and the Problem of "Equity" (1942-143) 18 Notre Dame Law Review 2, 114.

30. Civil Jurisdiction and Judgments Act 1982.

31. Citron, D.K., "Cyber Civil Rights" (2009) 89 Boston University Law Review 1, 61. a. Convention for the Protection of Human Rights and Fundamental Freedoms (As amended by Protocols Nos. 11 and 14, 4 November 1950, ETS 5. 213 UNTS 221).

32. Convention on Jurisdiction and the Enforcement of Judgments in Civil and Commercial Matters (Lugano Convention) 28 ILM 620 (1989).

33. Cooley, T.M., A Treatise on the Law of Torts, or the Wrongs which arise Independently of Contract (Chicago, Callaghan \& Company, 2nd Edn., 1888).

a. Co-operative Insurance Society Ltd v Argyll Stores (Holdings) Ltd [1998] AC 1 [1997] 3 All ER 297.

34. Cream Holdings and Imutran v Uncaged Campaigns Limited [2001] EMLR 563.

35. CTB v News Group Newspapers Ltd [2011] EWHC 1326 (QB) and 1334 (QB).

36. Dacre, P., Editor-in-Chief of Associated Newspapers, in 2008 - Speech to the Society of Editors, 9 November 2008.

37. Daubney v Cooper (1829) 109 E.R. 438; 10 B \& C 237.

38. Diennet v France (1996) 21 E.H.R.R. 554.

39. Directive 2000/31/EC of the European Parliament and of the Council of 8 June 2000. 
Manu, T., Moreno, F.R. (2016)

Is Social Media Challenging the Authority of the Judiciary? Rethinking the Effectiveness of Anonymised and Super Injunctions in the Age of the Internet

a. European Commission Directive 2000/31.

b. Emerson, T., "The Right of Privacy and Freedom of the Press" (1979) 14 Harvard

Civil Rights-Civil Liberties Law Review 2, 329.

40. European Union Accession to the ECHR: In The Opinion of the Advocate General in the CJEU Joined Cases C-203/15 and C-698/15 of the Tele2 AB.

41. Ex parte Wason (1869) LR 4 QB 573.

42. ETK v News Group Newspapers [2011] EWCA Civ 439.

43. French Code of Civil Procedure (Nouveau Code de Procedure Civile, Le Code De Procedure Civile Francais Traduit En Anglais) in English, (Ed) 2016.

44. Films Rover International Ltd v Cannon Film Sales Ltd [1986] 3 All ER 772.

45. G \& G v Wikimedia [2010] EMLR 14.

46. Gabbatt A., and Taylor, M., Scottish Newspaper Identifies Injunction Footballer (The Guardian, 22 May 2011).

47. Gavison, R., "Privacy and the Limits of Law" (1980) 89 Yale Law Journal 421.

48. Gerety, T., "Redefining Privacy" (1977) 12 Harvard Civil Rights - Civil Liberties Law Review 2, 233.

49. Glancy, D., "The Invention of the Right to Privacy" (1979) 21 Arizona Law Review 1, 1.

50. Glancy, D., "The Invention of the Right to Privacy" (1979) 21 Arizona Law Review 1, 1.

51. Gladstone, J.A., Determining Jurisdiction in Cyberspace: The "Zippo" Test or the "Effects" Test? (Informing Science InSITE - "Where Parallels Intersect", June 2003).

52. Godard v. Gray [1870] LR 6 QB. 139.

53. Goodwin v News Group Newspapers Ltd [2011] EMLR 502.

54. Gray v UVW [2010] EWHC 2637 (QB).

55. Groleau, JP., "Interlocutory Injunctions: Revisiting the Three-Pronged Test" (2008) 53 McGill Law Journal 269.

56. Halsbury's Laws of England 4th Ed. Reprint Vol. 8 issue 2.

57. Handyside v. United Kingdom [1976] 1 EHRR 737.

58. Harris v Harris [2001] 2 F.L.R. 895.

59. Hessel Yntema, "The Comity Doctrine” (1966) 65 Michigan Law Review 1, 9.

60. Hobbs v Tinling and Company Limited [1929] 2 K.B. 1.

61. Houlditch v. Marquis [1834] 8 Bligh N.S. 301; 2 CI \& F. 470.

62. Housing Group-South Ltd v Harris [2005] 4 ALL E.R. 1051 at 72.

63. Huber, U., Praelectiones Juris Civilis (Lectures on the Civil Law) on the Institute (Francofurtum ad Moenum, Gleditsch, first published in 1687).

64. Huber, U., De Jure Civitatis, Lib. III, Sect. IV, Cap. I., 14.

a. Human Rights Act 1998. Chapter 42.

65. Hansard, HC Deb, 23 May 2011.

66. Jack, M., Hutton, M., Johnson, C., Millar, D., Patrick, S., Sandall, A., (Eds) Parliamentary Practice (Erskine May: Butterworths Law, 23rd Revised Edn., 2004).

67. James, F., and Hazard, G., Civil Procedure (Boston, MA., Little Brown Books, 3rd Edn., 1985).

68. Jones v Pacaya Rubber \& Produce Co Ltd [1911] 1 K.B. 455. 
Manu, T., Moreno, F.R. (2016)

Is Social Media Challenging the Authority of the Judiciary? Rethinking the Effectiveness of Anonymised and Super Injunctions in the Age of the Internet

69. Joint Committee on Parliamentary Privilege (House of Lords and the House of Commons, HL 43-I / HC 214-I, Session 1998-1999).

70. JIH v News Group Newspapers Ltd [2011] EWCA Civ 42

71. Katz v. United States, 389 U.S. 347 (1967).

72. Kaye v Robertson and Sports Newspapers Ltd [1991] FSR 62.

a. Kennedy, K., Equitable Remedies and Principled Discretion: The Michigan

Experience (1997) 74 University of Detroit Mercy Law Review 4, 609.

73. Kittle, W., "Courts of Law and Equity-Why They Exist and Why They Differ" (19191920) 26 West Virginia Law Quarterly 21.

74. Koopman, S., (Ed.) Newspapers in International Librarianship: Papers Presented by the Newspapers at International Federation of Library Association General Conferences, (The Hague, Walter de Gruyter \& Co. 2003).

75. Lester, A., Five Ideas to Fight for: How Our Freedom is Under Threat and Why it Matters (London-Bloomsbury, Oneworld Publications, 2016).

76. Lorenzen, E., “Huber's De Conflictu Legum" (1919) 13 Illinois Law Review 375.

77. Lonrho v Fayed [1993] 1 WLR 1489.

78. Main, T., "Traditional Equity and Contemporary Procedure" (2003) 78 Washington Law Review 429.

79. Markesinis, B., The German Law of Torts: A Comparative Treatise (Oxford; Portland, Oregon, Hart Publishing, 2nd Edn., 1990).

80. McGhee J., (Ed.) Snell's Equity (Thomson Sweet \& Maxwell, 2005).

81. McGarrigle, P., "The Role of Foreign Judgments in Patent Litigation: A Perspective and Strategic Overview" (1998) 39 IDEA 1, 107.

82. McKennitt v Ash [2006] EWCA Civ 1714.

83. McKennitt v Ash [2008] QB 73.

84. Mcleod, R., "Injunction Junction: Remembering the Proper Function and Form of Equitable Relief in Trademark Law" (2006) 5 Duke Law \& Technology Review 1.

85. Merwin, E., The Principles of Equity and Equity Pleading (Indianapolis, BowenMerril, 1895).

86. Mill, J.S., On Liberty (London, Longman, Roberts, \& Green Co. 1859).

87. Morgan v Mich. [1737] 1 ATK. 408.

88. Mosley v News Group Newspapers Ltd [2008] EWHC 687 (QB).

89. Murray v MGN [2008] EWCA Civ 446, [2009] Ch 481.

90. Neill, E., Rites of Privacy and the Privacy Trade: On the Limits of Protection for the Self (Montreal McGill Queen's University Press, 2001).

a. New Patriotic Party v. Ghana Broadcasting Corp., (30 November 1993, Writ

No. 1/93).

91. Ntuli v Donald [2010] EWCA Civ 1276.

92. Offences under the Juries Act 1974.

93. Offences under the Contempt of Court Act 1981.

94. Paul, J., "The Transformation of International Comity" (2008) 71 Law and Contemporary Problems 3, 19.

95. Pepper v Hart [1993] AC 593.

96. PJS v News Group Newspapers Ltd [2016] UKSC 26.

70 DE GRUYTER Journal of legal studies Volume 18 Issue 32/2016 OPEN ISSN 2457-9017; Online ISSN 2392-7054. Web: publicatii.uvvg.ro/index.php/jls. Pages 39-87 
Manu, T., Moreno, F.R. (2016)

Is Social Media Challenging the Authority of the Judiciary? Rethinking the Effectiveness of Anonymised and Super Injunctions in the Age of the Internet

97. PJS v News Group Newspapers Ltd [2016] EWCA Civ 100.

98. Piggott F., The Law and Practice of the Courts of the United Kingdom Relating to Foreign Judgments and Parties Out of the Jurisdiction (London, W. Clowes and Sons, 2nd Ed., 1884).

99. Polaroid Corporation v Eastman Kodak Co [1977] RPC 379.

100.Plucknett, T., A Concise History of the Common Law (Indianapolis, Liberty Fund, 5th ed. 1956).

101.Plunkett, J., Imogen Thomas "Vindicated' after Footballer Drops Blackmail Claim" (The Guardian 15 December 2011).

102.Prosser, W., "Privacy" (1960) 48 California Law Review 3, 383.

103.Prince Albert v Strange (1849) 41 ER 1171, 1 Mac \& G 25 at 47.

104.Practice Guidance: Interim Non-Disclosure Orders (London, Master of the Rolls with effect from 1 August 2011).

105.Privacy and Injunctions (London, House of Lords House of Commons Joint Committee on Privacy and Injunctions, HL Paper 273, HC 1443, 12 March 2012).

106.Practice Guidance: Committal for Contempt [2013] 1 WLR 1326, dated 3 May 2013.

107.Practice Guidance (Committal Proceedings: Open Court) (No. 2) [2013] 1 WLR 1753, dated 4 June 2013.

108.President's Circular: Committals Family Court Practice 2024 at 2976, dated 2 August 2013.

109.R v Chaytor \& Others [2010] 3 WLR 1707.

110.R v Sussex Justices, Ex parte McCarthy ([1924] 1 KB 256, [1923] All ER Rep 233).

111.R (Binyam Mohamed) v Secretary of State for Foreign and Commonwealth Affairs [2010] EWCA Civ 65.

112.R v Chief Registrar of Friendly Societies, ex parte New Cross Building Society [1984] Q.B. 227.

113.R v Legal Aid Board ex parte Kaim Todner [1999] 1 QB 966.

114.Raack, D., “A History of Injunctions in England Before 1700” (1986) 61 Indiana Law Journal 4, 539.

115.Redmond-Bate v Director of Public Prosecutions [1999] 7 BHRC 375.

116.Regina v. Connor and another (Appellants) (On Appeal from the Court of Appeal (Criminal Division)). Regina v. Mirza (Appellant) (On Appeal from the Court of Appeal (Criminal Division)) (Conjoined Appeals) [2004] UKHL 2.

117.Re Guardian News and Media Ltd [2010] UKSC 1, [2010] 2 WLR 325.

118.Re JR 38 [2015] UKSC 42, [2015] 3 WLR 155.

119.Re S (A Child) (Identification: Restrictions on Publication) [2004] UKHL 47; [2005] 1 AC 593.

120.Re S (A Child) [2005] 1 AC 593.

121.Rembar, C., The Law of the Land: The Evolution of Our Legal System (New York, Simon \& Schuster, 1980).

122.Report of the Committee on Super-Injunctions: Super-Injunctions, Anonymised Injunctions and Open Justice (London, Master of the Rolls, 20 May 2011).

123. Reynolds v Times Newspapers Ltd [2001] 1 AC 12.

124. Restatement (Second) of Conflict of Laws, Reporter's Note to Comment g (1971). 
Manu, T., Moreno, F.R. (2016)

Is Social Media Challenging the Authority of the Judiciary? Rethinking the Effectiveness of Anonymised and Super Injunctions in the Age of the Internet

125.Richards N., and Solove, D., "Prosser's Privacy Law: A Mixed Legacy" (2010) 98 California Law Review 6, 1187.

126.RJW \& SJW v The Guardian News and Media Ltd ([2009] EWHC 2540 (QB).

127. Rozenberg, J., Privacy and the Press (New York, Oxford University Press, 2004).

128.Sabbagh D., and Halliday, J., Injunction Remains Despite MP's Revelation (The Guardian, 23 May 2011).

129.Scott v Scott [1913] A.C. 417.

130. Sedley, S., Lions under the Throne: Essays on the History of English Public Law (Cambridge, Cambridge University Press, 2015).

131. Sevems, R., "Nineteenth Century Equity: A Study in Law Reform" (1934) 12 ChicagoKent Law Review 2, 81.

132.Sipple v. Chronicle Publ'g Co., 201 Cal. Rptr. 665 (1984).

133. Social Media and Criminal Offences (London, House of Lords, HL 37, Communications Committee, First Report of Session 2014-2015).

134.Solove, D., “Conceptualizing Privacy” (2002) 90 California Law Review 4, 1087.

135.Smith v Peters [1875] L.R. Eq. 511.

136. Spry, I., The Principles of Equitable Remedies (London, Sweet \& Maxwell, 8th Edn., 2010).

137.Stephens, B., Chomsky J.B., Green, J., Hoffman, P., and Ratner M., (Eds.) International Human Rights Litigation in U.S. Courts (Martinus, Nijhoff, 2d Rev. Edition, 2008).

138.Stockdale v Hansard (1839) 9 Ad \& E 1.

139. Stuart Sime, A Practical Approach to Civil Procedure (New York, Oxford University Press, 11 Edition, 2014).

140.Subrin, S., "How Equity Conquered Common Law: The Federal Rules of Civil Procedure in Historical Perspective (1987) 135 University of Pennsylvania Law Review 909.

141.Terry v Persons Unknown [2010] 1 FCR 659.

142.The Case of Barbulescu v Romania [2016] Referral to the Grand Chamber (Application No. 61496/08).

143.The Civil Procedure Rules 1998 (SI1998/3132).

144. The County Courts Act 1984.

145.The Data Protection Act 1998, c. 29.

146. The Defamation Act 2013, c. 26.

147. The Judicial Committee of the Privy Council in Prebble v Television New Zealand Ltd [1995] 1 AC 321.

a. The Report of the Special Rapporteur on the Promotion and Protection of the Right to Freedom of Opinion and Expression David Kaye (Geneva, Human Rights Council, UN Doc. A/HRC/29/32, 22 May 2015).

148. The Special Rapporteur on Freedom of Expression (Frank La Rue, Geneva, United Nations Human Rights Council, UN Doc- A/HRC/23/40, 17 April 2013).

149.The Parliamentary Papers Act 1840, Chapter 93 and 4 Vict.

150.The Senior Courts Act 1971.

151.The Regulation of Investigatory Powers Act 2000, c. 23. 
Manu, T., Moreno, F.R. (2016)

Is Social Media Challenging the Authority of the Judiciary? Rethinking the Effectiveness of Anonymised and Super Injunctions in the Age of the Internet

152.The White Book (Vol. 1, Sweet \& Maxwell, 2011).

153.Thierer A., and Crews Jr., C., Who Rules the Net? Internet Governance and Jurisdiction (Washington, DC. Cato Institute 2003).

154. Thevarajah v Riordan [2016] 1 WLR 76.

155.Times Newspapers Ltd (Nos 1 and 2) v The United Kingdom [2009] EMLR 14 (Reference Application Nos. 3002/03 and 23676/03).

a. Von Hannover v Germany (No. 1) [2004] EMLR 379; (2005) 40 EHRR 1.

156. Wainwright \& Anor v. Home Office [2003] UKHL 53.

157.Warren, S., and Brandeis L., "The Right to Privacy" (1980) 4 Harvard Law Review 5, 193.

a. Weller v Associated Newspapers Ltd [2015] EWCA Civ 1176.

158. White, RW., "Enforcement of Foreign Judgments in Equity" (1982) 9 Sydney Law Review 3630.

159.Wrexham County Borough Council v Berry [2003] UKHL 26; [2003] 2 AC 558.

160. Yahoo!, Inc. v. La Ligue Contre LeRacisme et L'Antisemitisme, declaratory judgment of 7th November 2001, CRI 2002, 13 with remarks by Wittow, 169 F.Supp.2d 1181 (N. D. Cal., 2001).

161.Zuckerman, A., "Super Injunctions - Curiosity-Suppressant Orders Undermine the Rule of Law” (2010) 29 Civil Justice Quarterly 2, 131.

Websites

1. The Code for Crown Prosecutors, 2013. Available at: <https://www.cps.gov.uk/publications/docs/code_2013_accessible_english.pdf> [Accessed 1 October 2016].

2. Final Guidelines for Prosecutions Involving Social Media Communications (DPP, 20/06/2013). Available at:

<http://www.cps.gov.uk/legal/a_to_c/communications_sent_via_social_media/>

[Accessed 1 October 2016].

3. The Huffington Post. Available at:

<http://www.huffingtonpost.com/news/social-media-arab-spring/> [Accessed October 2016].

4. The Huffington Post. Available at: <http://www.huffingtonpost.co.uk/entry/injunction-celebrity-world-famous-marriagewho-had-an-affair_uk_570a5831e4b0fa55639d3842> [Accessed 12 September 2016].

5. "Privacy Injunctions Unsustainable, says Cameron". BBC website, 23 May 2011. Available at: <http://www.bbc.co.uk/news/uk-13498504>[Accessed 1 July 2016].

6. Social Media Prosecution Guidelines set out by Crown Office. BBC website, 14 December 2014. Available at: <http://www.bbc.co.uk/news/uk-scotland-30309411> [Accessed 1 October 2016].

7. Sunday Herald (Scottish Newspaper, 22 May 2011 Edition). Available at: <http://www.webdoodles.org/webimages/sundayherald22may2011.jpg> [Accessed 1 July 2016].

8. Sunday Herald Names Footballer Accused on Twitter. BBC website, 22 May 2011. Available at: <http://www.bbc.co.uk/news/uk-13491086> [Accessed 1 July 2016]. 


\section{Notes}

${ }^{1}$ Convention for the Protection of Human Rights and Fundamental Freedoms (As amended by Protocols Nos. 11 and 14, 4 November 1950, ETS 5. 213 UNTS 221).

2 The Report of the Special Rapporteur on the Promotion and Protection of the Right to Freedom of Opinion and Expression David Kaye (Geneva, Human Rights Council, UN Doc. A/HRC/29/32, 22 May 2015) at 6.

${ }^{3}$ Human Rights Act 1998. Chapter 42.

${ }^{4}$ Mosley v News Group Newspapers Ltd [2008] EWHC 687 (QB), para. 28, per Eady J, describing proportionality as a very well established methodology.

${ }^{5}$ Charter of Fundamental Rights of the European Union (Official Journal of the European Communities, 2000/C 364/01, 18.12.2000. 261 U.N.T.S. 140).

6 Thomas Emerson, "The Right of Privacy and Freedom of the Press" (1979) 14 Harvard Civil Rights-Civil Liberties Law Review 2, 329 at 359.

${ }^{7}$ Goodwin v News Group Newspapers Ltd [2011] EMLR 502, para. 85, per Tugendhat J. characterising privacy as confidentiality and intrusion.

${ }^{8}$ Id.

${ }^{9} \mathrm{EU}$ accession to the ECHR: In The Opinion of the Advocate General in the CJEU Joined Cases C-203/15 and C-698/15 of the Tele2 AB. Available at: $<$ http://curia.europa.eu/juris/document/document.jsf;jsessionid=9ea7d0f130d52f81da05e84 644d6853fdaba8968ff16.e34KaxiLc3eQc40LaxqMbN4Pa3mPe0?text=\&docid=181841\&p ageIndex $=0 \&$ doclang $=E N \&$ mode $=$ req \&dir $=\& o c c=$ first $\&$ part $=1 \&$ cid $=463222>[$ Accessed 1 September 2016] paras. 76, 77, and 78.

${ }^{10}$ Article 10(2) provides that: The exercise of these freedoms, since it carries with it duties and responsibilities, may be subject to such formalities, conditions, restrictions or penalties as are prescribed by law and are necessary in a democratic society, in the interests of national security, territorial integrity or public safety, for the prevention of disorder or crime, for the protection of health or morals, for the protection of the reputation or rights of others, for preventing the disclosure of information received in confidence, or for maintaining the authority and impartiality of the judiciary.

${ }^{11} I d$.

${ }^{12}$ Ibid. Emerson, note 6.

${ }^{13}$ Handyside v. United Kingdom [1976] 1 EHRR 737, para. 49.

${ }^{14}$ New Patriotic Party v. Ghana Broadcasting Corp., (30 November 1993, Writ No. 1/93) at 17 .

${ }^{15}$ See, Halsbury's Laws of England 4th Ed. Reprint Vol. 8 issue 2, para. 107 and cases there cited.

${ }^{16}$ PJS v News Group Newspapers Ltd [2016] UKSC 26, para. 21.

${ }^{17}$ Anthony Lester, Five Ideas to Fight for: How Our Freedom is Under Threat and Why it Matters (London-Bloomsbury, Oneworld Publications, 2016) at 152.

${ }^{18}$ Ibid. "Convention for the Protection of Human Rights and Fundamental Freedoms", note 1. 
19 The Special Rapporteur on Freedom of Expression (Frank La Rue, Geneva, United Nations Human Rights Council, UN Doc- A/HRC/23/40, 17 April 2013). Available at: <http://www.ohchr.org/Documents/HRBodies/HRCouncil/RegularSession/Session23/A.HR C.23.40_EN.pdf> [Accessed 2 September 2016] para. 27.

${ }^{20}$ Ibid. Emerson, note 6.

${ }^{21}$ David Raack, “A History of Injunctions in England Before 1700” (1986) 61 Indiana Law Journal 4, 539 at 592, raising the concern that some judgments were obtained by inequitable means.

${ }^{22}$ Polaroid Corporation v Eastman Kodak Co [1977] RPC 379, para. 395, per Buckley LJ.

${ }^{23}$ See, Section 37 of the Senior Courts Act 1971. See also, Section 38 of County Courts Act 1984.

${ }^{24}$ Wrexham County Borough Council v Berry [2003] UKHL 26; [2003] 2 AC 558, para. 31, per Lord Bingham.

${ }^{25}$ American Cyanimid Co. v Ethicon Ltd [1957] AC 396.

${ }^{26}$ Cream Holdings and Imutran v Uncaged Campaigns Limited [2001] EMLR 563 at para. 15.

${ }^{27}$ Ibid. American Cyanimid Co. v Ethicon Ltd, notes 25, para. 408, per Lord Diplock.

28 Note that at the EU level, injunctions are covered by Directive 2000/31/EC of the European Parliament and of the Council of 8 June 2000. In particular, Recitals 45 and 47.

${ }^{29}$ Cream Holdings v Uncaged Limited, note 26, para.16.

${ }^{30}$ Ibid. para. 17.

${ }^{31}$ Joshua Rozenberg, Privacy and the Press (New York, Oxford University Press, 2004) at 129.

${ }^{32}$ Godwin Busuttil, Free Speech v Privacy - The Big Debate, Preventing Publication of Private Information - When you can and when can cannot (London, Sweet \& Maxwell, 2009) at 4.

${ }^{33}$ RJW \& SJW v The Guardian News and Media Ltd ([2009] EWHC 2540 (QB), para. 7.A(b), per Maddison J's order. Also known as Trafigura v Guardian News and Media Limited. See, Ntuli v Donald [2010] EWCA Civ 1276, para. 43. See also, Gray v UVW [2010] EWHC 2637 (QB) para. 19.

34 The Civil Procedure Rules 1998 (SI1998/3132). Note that privacy orders are generally acceptable due to the private nature of those proceedings and the historical practice of the Family Division. See, Harris v Harris [2001] 2 F.L.R. 895, para. 345-353.

${ }^{35}$ Re Guardian News and Media Ltd [2010] UKSC 1, [2010] 2 WLR 325, para. 22. Lord Rodger referred to the "recent efflorescence of anonymity orders",

${ }^{36}$ Ntuli v Donald, note 33 at 47. See also, Report of the Committee on Super-Injunctions: Super-Injunctions, Anonymised Injunctions and Open Justice (London, Master of the Rolls, 20 May 2011). Available at: <https://www.judiciary.gov.uk/wpcontent/uploads/JCO/Documents/Reports/super-injunction-report-20052011.pdf>

[Accessed 12 September 2016] at 1, para. 1.2.

${ }^{37}$ Attorney-General v Newspaper Publishing Plc [1988] Ch 333 at 375 \& 380.

${ }^{38}$ Attorney-General v Punch Ltd \& Another [2003] 1 A.C. 1046 at 1066.

39 "Report of the Committee on Super-Injunctions" note 36, para. 2. 6. 
${ }^{40} I d$. at 23 , para. 2.23 .

${ }^{41}$ Terry v Persons Unknown [2010] 1 FCR 659 at 24.

42 "Report of the Committee on Super-Injunctions" note 36, at iv, para.3. Terry at 138. See also, G \& G v Wikimedia [2010] EMLR 14 at 41.

${ }^{43}$ Privacy and Injunctions (London, House of Lords House of Commons Joint Committee on Privacy and Injunctions, HL Paper 273, HC 1443, 12 March 2012). Available at: <http://www.publications.parliament.uk/pa/jt201012/jtselect/jtprivinj/273/273.pdf>

[Accessed 1 July 2016] at para. 33, citing Paul Dacre, Editor-in-Chief of Associated Newspapers, in 2008 - Speech to the Society of Editors, 9 November 2008 that the courts are creating a privacy law "through the back door".

${ }^{44} I d$.

45 "PJS v News Group Newspapers" note 16, para. 1.

${ }^{46} I d$.

${ }^{47}$ Ibid. para. 2.

${ }^{48} \mathrm{Ibid}$. para. 8, mentioning the US in particular.

${ }^{49}$ Ibid. para. 56. See, Thevarajah v Riordan [2016] 1 WLR 76 para. 18 citing Buckley LJ in

Chanel Ltd v F W Woolworth \& Co Ltd [1985] 1 WLR 485, para. 492-493.

${ }^{50}$ PJS v News Group Newspapers Ltd [2016] EWCA Civ 100, para. 39.

${ }^{51}$ CTB v News Group Newspapers Ltd [2011] EWHC 1326 (QB) and 1334 (QB) para. 3, per Tugendhat J.

52 "PJS v News Group Newspapers" note 50, para. 53

53 "PJS v News Group Newspapers" note 16, para. 79, dismissing the appeal at para. 93.

${ }^{54}$ Ibid. para. 19.

${ }_{56}^{55}$ Ibid. para. 53.

${ }_{57}^{56}$ Ibid. para. 18 (vi).

${ }^{57}$ Ibid. para.20, citing, Re S (A Child) (Identification: Restrictions on Publication) [2004] UKHL 47; [2005] 1 AC 593, para. 17, per Lord Steyn; McKennitt v Ash [2006] EWCA Civ 1714; [2008] QB 73, para. 47, per Buxton LJ; and "Mosley v News Group Newspapers", note 4), para. 28, per Eady J.

58 "PJS v News Group Newspapers" note 16, para. 51.

${ }^{59}$ Ibid. para. 71.

60 "PJS v News Group Newspapers" note 36, para. 47(v). See also, "PJS v News Group Newspapers" note 50, para. 21.

${ }^{61}$ Ibid. para. 70, per Lord Mance.

${ }^{62} \mathrm{Ibid}$. paras. $47 \& 57$.

${ }^{63}$ Ibid. para. 18(iv). See also, "PJS v News Group Newspapers" note 50, para. 45.

${ }^{64} \mathrm{Ibid}$. PJS UKSC, para. 18(iv). See also, PJS EWCA, para. 45.

${ }^{65}$ PJS v UKSC, para. 18(1), stating that knowledge of the relevant matters is now so widespread that confidentiality has probably been lost.

${ }^{66}$ Ibid. para. 1.

${ }^{67}$ Dorothy Glancy, "The Invention of the Right to Privacy" (1979) 21 Arizona Law Review 1,1 at 1 . 
${ }^{68}$ Elizabeth Neill, Rites of Privacy and the Privacy Trade: On the Limits of Protection for the Self (Montreal McGill Queen's University Press, 2001) at 6.

${ }^{69}$ Samuel Warren and Louis Brandeis, "The Right to Privacy" (1980) 4 Harvard Law Review 5, 193.

${ }^{70} I d$.

${ }^{71} \mathrm{Ibid}$. at 195.

${ }^{72}$ Id.

${ }^{73} \mathrm{Ibid}$. at 175 .

${ }^{74} \mathrm{Ibid}$. at 196.

${ }^{75}$ William Prosser, "Privacy" (1960) 48 California Law Review 3, 383 at 384.

${ }^{76}$ Emerson, note 6 at 330.

${ }^{77}$ Ruth Gavison, "Privacy and the Limits of Law" (1980) 89 Yale Law Journal 421 at 422 lamenting the lack of a useful, distinct, and coherent concept of privacy.

${ }^{78}$ Daniel Solove, “Conceptualizing Privacy” (2002) 90 California Law Review 4, 1087 at 1089.

79 William Beaney, "The Right to Privacy and American Law" (1966) 31 Law and Contemporary Problems 2, 253 at 255.

${ }^{80}$ Solove, note 78 at 1090.

81 "Privacy and Injunctions", note 43, Ch. 2, para. 9.

${ }^{82}$ Emerson, note 6 at 337.

${ }^{83}$ Thomas McIntyre Cooley, A Treatise on the Law of Torts, or the Wrongs which arise Independently of Contract (Chicago, Callaghan \& Company, 2nd Edn., 1888) at 29.

84 "Privacy and Injunctions", note 43, Ch. 2, para. 9.

${ }^{85}$ Emerson, note 6 at 341 .

${ }^{86}$ Tom Gerety, "Redefining Privacy" (1977) 12 Harvard Civil Rights - Civil Liberties Law Review 2, 233 at 236.

${ }^{87}$ Paul Bender, Privacies of Life (New York, Harper's Magazine, April 1974) at 36. Reprinted in part in Political and Civil Rights, in Paul Bender, Thomas Emerson, David Haber, Norman Dorsen and Burt Neuborne, Political and Civil Rights in the United States (Vol. 1, Fourth Edn. Little, Brown and Company; 1976) at 20-25, defining privacy as "the freedom to be one's self" and stressing that it is confined to activities that "do not affect the legitimate interests" of others.

88 Edward Bloustein, "Privacy as an Aspect of Human Dignity: An Answer to Dean Prosser" (1964) 39 The New York University Law Review 962 at 1005.

${ }^{89}$ Kaye v Robertson and Sports Newspapers Ltd [1991] FSR 62, at 71, per Leggatt LJ, 'This right has so long been disregarded here that it can be recognised now only by the legislature.' Ibid. per Glidewell LJ, at 66, illustrating "the desirability of Parliament considering whether and in what circumstances statutory provision can be made to protect the privacy of individuals". Professor Julian Petley, Professor of Journalism and Screen Media at Brunel University and Chair of the Campaign for Press and Broadcasting Freedom and Max Mosley in his written evidence to Parliament. See, Privacy and Injunctions, notes 44 , para. 34 ..

${ }^{90}$ Emerson, note 6 at 340 . 
Is Social Media Challenging the Authority of the Judiciary? Rethinking the Effectiveness of Anonymised and Super Injunctions in the Age of the Internet

${ }^{91}$ Id.

92 Ibid. at 339.

${ }^{93}$ Prince Albert v Strange (1849) 41 ER 1171, 1 Mac \& G 25 at 47, per Lord Cottenham LC.

${ }^{94}$ Emerson, note 6 at 352.

${ }^{95} \mathrm{Ibid}$. at 359.

96 "Privacy and Injunctions", note 43, para. 12. See also, Basil Markesinis, The German Law of Torts: A Comparative Treatise (Oxford; Portland, Oregon, Hart Publishing, 2nd Edn., 1990) at 316.

${ }^{97}$ In Attorney-General v Guardian Newspapers Ltd (No.2) [1990] 1 A.C. 109 at 255, Lord Keith referred to cases 'where the breach of confidence involves no more than an invasion of personal privacy'.

${ }^{98}$ Bernstein v. Skyviews Ltd. [1978] Q.B. 479 at 489G, per Griffiths J.

99 "Kaye v Robertson and Sports Newspapers", note 89 at 70, per Bingham LJ. 'This case nonetheless highlights, yet again, the failure of both the common law of England and statute to protect in an effective way the personal privacy of individual citizens'.

${ }^{100}$ Wainwright \& Anor v. Home Office [2003] UKHL 53, para.19.

101 "Privacy and Injunctions", note 43, para. 13, citing the Protection from Harassment Act 1997 and the Data Protection Act 1998.

${ }^{102}$ Ibid. at para. 14.

${ }^{103}$ Emerson, note 6 at 349.

${ }^{104} \mathrm{Ibid}$. at 349.

${ }^{105} \mathrm{Ibid}$. at 345 .

106 Ibid. at 345, footnote 54, citing John Stuart Mill, On Liberty (London, Longman, Roberts, \& Green Co. 1859).

${ }^{107} \mathrm{Ibid}$. at 342 .

${ }^{108}$ Ibid. at 331 .

${ }^{109}$ Ibid. at 349 .

${ }^{110}$ Branzburg v. Hayes, 408 U.S. 665 (1972) para. 681-682.

${ }^{111}$ Sjoerd Koopman (Ed.), Newspapers in International Librarianship: Papers Presented by the Newspapers at International Federation of Library Association General Conferences (The Hague, Walter de Gruyter \& Co. 2003) at 124.

${ }^{112}$ Ibid. New Patriotic Party v. Ghana Broadcasting Corp., note 14.

113 "Privacy and Injunctions", note 43 at para. 10.

${ }^{114}$ Emerson, note 6 at 356 .

${ }^{115}$ Emerson, note 6 at 349 .

${ }^{116}$ Ibid.

117 "Privacy and Injunctions", note 43 at para. 28.

${ }^{118}$ Reynolds v Times Newspapers Ltd [2001] 1 AC 12, at 190.

${ }^{119}$ Katz v. United States, 389 U.S. 347 (1967). A person must demonstrate an "actual (subjective) expectation of privacy" and "the expectation [must] be one that society is prepared to recognise as reasonable" Ibid. at 360-361, Justice Harlan's concurring opinion. ${ }^{120}$ [2004] UKHL 22, para. 99, per Lord Hope \& para. 154, per Baroness Hale. 
121 "Privacy and Injunctions", note 43 at para. 17.

${ }^{122}$ Murray v MGN [2008] EWCA Civ 446, [2009] Ch 481 at para. 35.

${ }^{123}$ Re JR 38 [2015] UKSC 42, [2015] 3 WLR 155, para. 88, per Lord Toulson. Weller v Associated Newspapers Ltd [2015] EWCA Civ 1176, para. 15.

124 "Privacy and Injunctions", note 43 at para. 17(1).

${ }^{125}$ Ibid. Murray v Express Newspaper, note 122. "Privacy and Injunctions", note 44, para. $17(2)$.

${ }^{126}$ Lord Steyn in Re S (A Child) [2005] 1 AC 593, para. 17 describes 'an intense focus on the comparative importance of the specific rights being claimed'.

127 "Campbell v MGN Limited", note 120 at 55, per Lord Hoffmann; at 141, per Baroness Hale of Richmond.

${ }^{128}$ Ibid. at 118 .

129 "Privacy and Injunctions", note 43 at para. 19.

${ }^{130}$ Emerson, note 6 at 355 .

131 "Privacy and Injunctions", note 43 at para. 42.

${ }_{132}$ Ibid. para. 50.

${ }^{133}$ For example, Sections 58(7) of the Regulation of Investigatory Powers Act 2000, c. 23; Section 31(3)(c) of the Data Protection Act 1998, c. 29. It is also referred to under Section 4 of the Defamation Act 2013, c. 26 but left undefined subject to the reasonable belief of the defendant.

${ }^{134}$ ETK v News Group Newspapers [2011] EWCA Civ 439 at 23. The contribution that the publication of information in an article would make to a debate of general interest was described as the "decisive factor" in balancing freedom of expression against privacy.

${ }^{135}$ Von Hannover v Germany (No. 1) [2004] EMLR 379; (2005) 40 EHRR 1, at para. 76.

136 "Privacy and Injunctions", note 43 at para. 82.

${ }^{137}$ McKennitt v Ash [2008] QB 73, para. 64. See also "Campbell v MGN", note 120 at 143.

138 "Privacy and Injunctions", note 43 at para. 89.

${ }^{139}$ A v B plc and C [2002] EWCA Civ 337, para. 11.

${ }^{140}$ McKennitt v Ash", note 137, para. 62.

${ }^{141}$ Ibid. para. 64.

142 Kevin Kennedy, Equitable Remedies and Principled Discretion: The Michigan Experience (1997) 74 University of Detroit Mercy Law Review 4, 609 at 610.

${ }^{143}$ Charles Rembar, The Law of the Land: The Evolution of Our Legal System (New York, Simon \& Schuster, 1980) at 275.

144 See, Stuart Sime, A Practical Approach to Civil Procedure (New York, Oxford University Press, 11 Edition, 2014) para. 43.

145 Jones v Pacaya Rubber \& Produce Co Ltd [1911] 1 K.B. 455 at 457. See also, “Attorney-General v Punch", note 38, paras. 1054-1055.

${ }^{146}$ John McGhee (Ed.) Snell's Equity (Thomson Sweet \& Maxwell, 2005) at 404. See also, Smith v Peters [1875] L.R. Eq. 511 at 513.

${ }^{147}$ Sipple v. Chronicle Publ'g Co., 201 Cal. Rptr. 665 (1984).

148 "Privacy and Injunctions", note 43, para. 51. 
149 The rule in Bonnard v Perryman [1891] 2 Ch 269 at 284, provides that an interim injunction will not be granted unless it is clear that no defence will succeed at trial. Per Lord Coleridge CJ.

${ }^{150}$ Lonrho v Fayed [1993] 1 WLR 1489 at 1502. Per Stuart-Smith LJ, 'No one has a right to a reputation which is unmerited. Accordingly, one can only suffer an injury to reputation if what is said is false. In defamation the falsity of the libel or slander is presumed; but justification is a complete defence.

${ }_{151}$ Theodore Plucknett, A Concise History of the Common Law (Indianapolis, Liberty Fund, 5th ed. 1956) at 667-680.

${ }^{152}$ Raack, note 21 at 551.

${ }^{153}$ Plucknett, note 151 at $667-681$.

${ }^{154}$ Kennedy, note 142 at 616.

${ }^{155}$ Thomas Main, "Traditional Equity and Contemporary Procedure" (2003) 78 Washington Law Review 429 at 514.

${ }^{156}$ Kennedy, note 142 at 610.

${ }^{157}$ Raack, note 21 at 541.

158 Anton-Hermann Chroust, The "Common Good" and the Problem of "Equity" (1942143) 18 Notre Dame Law Review 2, 114 at 117. In the Philosophy of Law of St. Thomas Aquinas.

${ }^{159}$ Colin Campbell, "The Court of Equity-A Theory of its Jurisdiction" (1903) 15 Green Bag 108 at 110, noting the intimacy of the relations among the basic principles of natural justice, equity, honesty, generosity and good conscience.

${ }^{160}$ Stephen Subrin, "How Equity Conquered Common Law: The Federal Rules of Civil Procedure in Historical Perspective (1987) 135 University of Pennsylvania Law Review 909 at 983 , stating that equity has no boundaries.

${ }^{161}$ Ibid. Main, note 15.

${ }^{162}$ Fleming James and Geoffrey Hazard, Civil Procedure (Boston, MA., Little Brown Books, 3rd Edn., 1985) at 16.

${ }^{163}$ Subrin, note 160 at 920 , mentioning that common law was the more confining, rigid and predictable system; equity was more flexible, discretionary, and individualised.

164 “American Cyanamid", note 25, per Lord Diplock.

${ }^{165}$ Beecham Group Ltd v Bristol Laboratories Pty Ltd (1968) 118 CLR 618, at 622-623

${ }^{166}$ A Treatise on the Law and Practice of Injunctions (Philadelphia, Blackstone, 3rd ed. $1889)$ at 13. See, Jean-Philippe Groleau, "Interlocutory Injunctions: Revisiting the ThreePronged Test" (2008) 53 McGill Law Journal 269, at 272.

167 "American Cyanamid", note 25.

${ }^{168}$ Ryan Mcleod, "Injunction Junction: Remembering the Proper Function and Form of Equitable Relief in Trademark Law" (2006) 5 Duke Law \& Technology Review 1 at para. 10.

169 “American Cyanamid”, note 25.

${ }^{170}$ CPR 25.2(1).

${ }^{171}$ Kennedy, note 142 at 614 , stating that principled discretion is the guiding principle for any judge asked to grant equitable relief. 
Is Social Media Challenging the Authority of the Judiciary? Rethinking the Effectiveness of Anonymised and Super Injunctions in the Age of the Internet

172 Ibid. at 654 .

${ }^{173} 36$ \& 37 Vict c. 66. Note that CPR 25.3 and CPR PD25A (1) - (5) apply to all interim injunction applications, including those for interim non-disclosure orders.

${ }^{174}$ Kennedy, note 142 at 655.

${ }^{175} \mathrm{Id}$.

176 "Privacy and Injunctions", note 43 at para. 52. Cream Holdings v Uncaged Limited, note 26 at para. 15.

${ }^{177}$ HL Deb, 24 November 1997, col 772.

${ }^{178}$ Ibid., col 785.

179 "Privacy and Injunctions", note 43 at para. 52.

${ }^{180} \mathrm{Ibid}$. at para. 60

181 "American Cyanamid Co v Ethicon Ltd", note 25 at 407-408.

${ }^{182}$ Cream Holdings v Uncaged Limited, note 26, at para. 12.

${ }^{183} \mathrm{Ibid}$. at 22 - 23.

${ }^{184}$ Practice Guidance: Interim Non-Disclosure Orders (London, Master of the Rolls with effect from 1 August 2011).

${ }^{185}$ Cream Holdings v Uncaged Limited, note 26 at para. 13.

${ }^{186} \mathrm{Id}$.

${ }^{187}$ Privacy and Injunctions", note 43 at para. 54.

${ }^{188}$ Hansard, HC Deb, 2 July 1998, col 536.

${ }^{189}$ Privacy and Injunctions", note 43 at para. 59.

${ }^{190}$ Hansard, HC Deb, 2 July 1998, col 536.

${ }^{191}$ Written evidence submitted by the Newspaper Society to House of Lords House of Commons Joint Committee on Privacy and Injunctions, 2011, para. 1. See also, Privacy and Injunctions", note 44 para. 61.

192 Adrian Zuckerman, "Super Injunctions - Curiosity-Suppressant Orders Undermine the Rule of Law" (2010) 29 Civil Justice Quarterly 2, 131 at 133.

${ }^{193}$ JIH v News Group Newspapers Ltd [2011] EWCA Civ 42, para. 21(3) reasoning that anonymity orders are a derogation from the principle of open justice and an interference with the Article 10 rights of the public at large.

${ }^{194} \mathrm{Ibid}$. at 21(1) \& (2).

195 "Re Guardian News and Media", note 35, para. 22. Lord Rodger referred to the "recent efflorescence of anonymity orders",

${ }^{196}$ Kennedy, note 142 at 616.

${ }^{197}$ Cayne -v- Global Natural Resources Plc [1984] 1 All ER 225 at 235 \& 237, per May L.J.

${ }^{198}$ Films Rover International Ltd v Cannon Film Sales Ltd [1986] 3 All ER 772, at 780781.

199 "Report of the Committee on Super-Injunctions" note 36, at iv, para. 2.

200 "In re Guardian News and Media Ltd", note 35 at $1 \& 2$.

${ }^{201} \mathrm{R} v$ Legal Aid Board ex parte Kaim Todner [1999] 1 QB 966, at 977.

${ }^{202}$ Zuckerman, note 192 at 134.

${ }^{203}$ Hansard, HC Deb, 23 May 2011, cols 633-4. 
${ }^{204}$ CPR 39.2. Article 6(1) of the HRA, 1998 provides that: In the determination of his civil rights and obligations or of any criminal charge against him, everyone is entitled to a fair and public hearing within a reasonable time by an independent and impartial tribunal established by law. Judgment shall be pronounced publicly but the press and public may be excluded from all or part of the trial in the interests of morals, public order or national security in a democratic society, where the interests of juveniles or the protection of the private life of the parties so require, or to the extent strictly necessary in the opinion of the court in special circumstances where publicity would prejudice the interests of justice.

${ }^{205}$ Daubney v Cooper (1829) 109 E.R. 438; 10 B \& C 237 at 240. Scott v Scott [1913] A.C. 417 at 438 , per Lord Haldane LC.

206 Ibid.

207 Scott v Scott [1913] A.C. 417, at 473. See also, Attorney General v Leveller Magazine [1979] A.C. 440 at 449-450.

${ }^{208}$ Scott v Scott [1913] A.C. 417 at 463; and Lord Shaw at 476; Axen v Germany (A/72) (1984) 6 E.H.R.R. 195 at para. 1.17.

${ }^{209}$ Chapter 54.

${ }^{210}$ R v Sussex Justices, Ex parte McCarthy ([1924] 1 KB 256, [1923] All ER Rep 233) per Lord Hewart CJ.

${ }^{211}$ Ibid. at 259. See also, Hobbs v Tinling and Company Limited [1929] 2 K.B. 1 at 48.

${ }^{212}$ R (Binyam Mohamed) v Secretary of State for Foreign and Commonwealth Affairs [2010] EWCA Civ 65 at 39. See also, Diennet v France (1996) 21 E.H.R.R. 554 at 33.

213 “Axen v Germany", note 208 at 25.

${ }^{214}$ Zuckerman, note 192 at 132.

215 "JIH v News Group Newspapers", note 193 at 38, observing that identification of the claimant will be more likely to result in public speculation.

${ }^{216} \mathrm{Id}$.

${ }^{217}$ Ibid. Zuckerman, note 214

${ }^{218}$ Id.

${ }^{219}$ Scott v Scott [1913] A.C. 417 at 437, per Lord Haldane LC.

220 "Report of the Committee on Super-Injunctions" note 36, para. 1.37.

221 "Privacy and Injunctions", note 43 at para. 64.

222 "Scott v Scott", note 219 at 445-446, Lord Loreburn and reiterated by Lord Diplock in 1979 in A-G v Leveller. [A-G v Leveller Magazine Ltd [1979] A.C. 440 at 450.

${ }^{223} \mathrm{R}$ v Chief Registrar of Friendly Societies, ex parte New Cross Building Society [1984] Q.B. 227 at 235.

${ }^{224}$ "Terry v Persons Unknown", note 41at 107, Tugendhat J. See also, Moat Housing Group-South Ltd v Harris [2005] 4 ALL E.R. 1051 at 72, per Brooke LJ.

225 "JIH v News Group Newspapers", note 193, para. 22.

${ }^{226}$ The White Book (Vol. 1, Sweet \& Maxwell, 2011) at 39.2.7.

${ }^{227}$ AMM v HXW [2010] EWHC 2457 (QB) at 34, per Tugendhat J.

228 Social Media and Criminal Offences (London, House of Lords, HL 37, Communications Committee, First Report of Session 2014-2015) ch. 2, para7. ${ }^{229} I d$. 
${ }^{230} I d$.

231 "Privacy and Injunctions", note 43, para. 92.

${ }^{232}$ See, Ahmet Yildirim v Turkey (ECHR 548, No.3111/10, 2012) para. 54.

233 Times Newspapers Ltd (Nos 1 and 2) v The United Kingdom [2009] EMLR 14 (Reference Application Nos. 3002/03 and 23676/03) para. 27.

${ }^{234}$ Sean Aday, Henry Farrell, Marc Lynch, John Sides and Deen Freelon "New Media and Conflict After the Arab Spring" (Washington DC. United States Institute of Peace, Peaceworks No. 80. Blogs and Bullets II, 2012). See also, The Huffington Post. Available at:

<http://www.huffingtonpost.com/news/social-media-arab-spring/> [Accessed 1 October 2016].

235 "Privacy and Injunctions", note 43, para. 93.

${ }^{236}$ The Case of Barbulescu v Romania [2016] Referral to the Grand Chamber (Application No. 61496/08) para. 3.

${ }^{237}$ Ibid. para. 3, Pinto de Albuquerque's opinion.

238 Ibid. para. 2.

${ }^{239}$ Ibid. para. 28.

${ }^{240}$ Raack, note 21 at 541.

${ }^{241}$ Practice Guidance: Committal for Contempt [2013] 1 WLR 1326, dated 3 May 2013; Practice Guidance (Committal Proceedings: Open Court) (No. 2) [2013] 1 WLR 1753, dated 4 June 2013; and President's Circular: Committals Family Court Practice 2024 at 2976, dated 2 August 2013.

${ }^{242}$ Chapter 27.

${ }^{243}$ Chapter 21.

${ }^{244}$ Section 1 of the Contempt Act 1981 chapter 49.

${ }^{245}$ Co-operative Insurance Society Ltd v Argyll Stores (Holdings) Ltd [1998] AC 1, at 1213; [1997] 3 All ER 297, at 1302-1303.

246 "Privacy and Injunctions", note 43, para. 91.

247 Warren Kittle, "Courts of Law and Equity-Why They Exist and Why They Differ" (1919-1920) 26 West Virginia Law Quarterly 21 at 29. See also, Elias Merwin, The Principles of Equity and Equity Pleading (Indianapolis, Bowen-Merril, 1895) at 17.

${ }^{248}$ Black's Law Dictionary (West Publishing Co., Rev. 5th ed. 1979) at 705.

249 Robert Sevems, "Nineteenth Century Equity: A Study in Law Reform" (1934) 12 Chicago-Kent Law Review 2, 81 at 82.

250 "Privacy and Injunctions", note 43, para. 103.

${ }^{251}$ Ibid. para. 102

252 Final Guidelines for Prosecutions Involving Social Media Communications (DPP, 20/06/2013).

253 "Privacy and Injunctions", note 43, para. 103.

${ }^{254}$ Ibid. para. 104.

${ }^{255}$ Offences under the Juries Act 1974; Offences under the Contempt of Court Act 1981. 
Manu, T., Moreno, F.R. (2016)

Is Social Media Challenging the Authority of the Judiciary? Rethinking the Effectiveness of Anonymised and Super Injunctions in the Age of the Internet

256 "Final Guidelines for Prosecutions Involving Social Media Communications ", note 252.

257 Social Media Prosecution Guidelines set out by Crown Office. BBC website, 14 December 2014. Available at: <http://www.bbc.co.uk/news/uk-scotland-30309411> [Accessed 1 October 2016].

258 "Final Guidelines for Prosecutions Involving Social Media Communications", note 252. ${ }^{259} I d$.

${ }^{260}$ Redmond-Bate v Director of Public Prosecutions [1999] 7 BHRC 375, para. 20, per Sedley LJ emphasised that under the Public Order Act 1986. See also, Stephen Sedley, Lions under the Throne: Essays on the History of English Public Law (Cambridge, Cambridge University Press, 2015) at 201.

${ }^{261}$ [2005] EWHC 2154 (Admin), para. 5.

262 The Code for Crown Prosecutors, 2013. Available at: <https://www.cps.gov.uk/publications/docs/code_2013_accessible_english.pdf> [Accessed 1 October 2016].

${ }^{263}$ Ian Spry, The Principles of Equitable Remedies (London, Sweet \& Maxwell, 8th Edn., 2010) at 331.

${ }^{264}$ Convention on Jurisdiction and the Enforcement of Judgments in Civil and Commercial Matters (Lugano Convention) 28 ILM 620 (1989). Preamble: ANXIOUS to strengthen the legal protection of persons in national territories - CONSIDERING that it is necessary to determine the international jurisdiction of their courts, to facilitate recognition and to introduce an expeditious procedure for securing the enforcement of judgments, authentic instruments and court settlements, and DESIRING to ensure as uniform interpretation. [emphasis added].

${ }^{265}$ Morgan v Mich. [1737] 1 ATK. 408, cited in RW White, "Enforcement of Foreign Judgments in Equity" (1982) 9 Sydney Law Review 3630 at 632.

${ }^{266}$ Houlditch v. Marquis [1834] 8 Bligh N.S. 301; 2 CI \& F. 470.

${ }^{267}$ Ibid. White.

${ }^{268}$ Black's Law Dictionary (ed.) Bryan Garner (Thomson West; 10th Edition, 2014) at 324, defining comity as 'a practice among different political entities (as countries, states, or courts of different jurisdictions) involving the mutual recognition of legislative, executive and judicial acts'.

${ }^{269}$ Ulrich Huber, Praelectiones Juris Civilis (Lectures on the Civil Law) on the Institute (Francofurtum ad Moenum, Gleditsch, first published in 1687) pt. 2, bk. 1, tit. 3, implying that 'everywhere persons enjoy and are subject to the law which persons of the same class enjoy and are subject to in that other place'. See, Ernest Lorenzen, "Huber's De Conflictu Legum" (1919) 13 Illinois Law Review 375 at 379. See also, Hessel Yntema, "The Comity Doctrine" (1966) 65 Michigan Law Review 1, 9, at 9, citing Ulrik Huber, De Jure Civitatis, Lib. III, Sect. IV, Cap. I., 14.

${ }^{270}$ Beth Stephens, Judith Brown Chomsky, Jennifer Green, Paul Hoffman, and Michael Ratner (Eds.) International Human Rights Litigation in U.S. Courts (Martinus, Nijhoff, 2d Rev. Edition, 2008) at 355, stating that one of the more confusing doctrines evoked in cases touching upon the interests of foreign states. 
271 Joel Paul, "The Transformation of International Comity" (2008) 71 Law and Contemporary Problems 3, 19 at 19-20.

${ }^{272} \mathrm{Ibid}$. at 23, stating that the idea of comity was introduced into English law by Lord Mansfield.

${ }^{273} \mathrm{Ibid}$. at 24, stating that comity is consensual, not obligatory. See, Lorenzen, note 269 at 378 , observing that comity is a mere concession that such state made on grounds of convenience and utility, and not as the result of a binding obligation or duty.

${ }^{274}$ Godard v. Gray [1870] LR 6 QB. 139. For an elaborate overview of the British cases that served as authorities for the creation of this doctrine, see, Francis Piggott, The Law and Practice of the Courts of the United Kingdom Relating to Foreign Judgments and Parties Out of the Jurisdiction (London, W. Clowes and Sons, 2nd Ed., 1884) at 5.

${ }^{275}$ Russell v. Smyth (1842) 9 M. \& W. 810.

${ }^{276}$ Guyot v Hilton [1895] 159, at 160.

277 Julia Alpert Gladstone, Determining Jurisdiction in Cyberspace: The "Zippo" Test or the "Effects" Test? (Informing Science InSITE - "Where Parallels Intersect", June 2003) at 114.

${ }^{278} I d$.

${ }^{279} \mathrm{Id}$.

280 "Privacy and Injunctions", note 43, para. 99

281 Adam Thierer and Clyde Crews Jr., Who Rules the Net? Internet Governance and Jurisdiction (Washington, DC. Cato Institute 2003) at xv.

${ }^{282}$ Phillip McGarrigle, "The Role of Foreign Judgments in Patent Litigation: A Perspective and Strategic Overview" (1998) 39 IDEA 1, 107 at 109, rejecting comity as a device that is poorly defined and understood.

${ }^{283}$ Yahoo!, Inc. v. La Ligue Contre LeRacisme et L'Antisemitisme, declaratory judgment of 7th November 2001, CRI 2002, 13 with remarks by Wittow, 169 F.Supp.2d 1181 (N. D. Cal., 2001).

${ }^{284}$ Note that in France, the French Code of Civil Procedure (Nouveau Code de Procedure Civile, Le Code De Procedure Civile Francais Traduit En Anglais) in English, 2016 (Ed). Section 509, states that foreign judgments are enforceable in France to the extent permissible under French law.

${ }_{285}$ Restatement (Second) of Conflict of Laws, § 102, Reporter's Note to Comment g (1971).

${ }^{286}$ Neil Richards and Daniel Solove, "Prosser's Privacy Law: A Mixed Legacy" (2010) 98 California Law Review 6, 1187 at 1889.

287 "Privacy and Injunctions", note 43, para. 96.

${ }^{288}$ Ibid. para. 96.

289 "The Report of the Special Rapporteur on the Promotion and Protection of the Right to Freedom of Opinion and Expression", note 2, at $4 \& 5$.

${ }^{290} I d$.

${ }^{291} I d$.

${ }^{292} I d$.

293 "Privacy and Injunctions", note 43, para. 94. 
${ }^{294} \mathrm{Ibid}$. at para. 94.

${ }^{295}$ Chapter 27.

296 "Privacy and Injunctions", note 43, para. 70.

${ }^{297}$ Civil Jurisdiction and Judgments Act 1982. Section 2 of Schedule 7 "Enforcement of UK Judgement (non-money provisions)"

${ }^{298}$ Ibid. "Lugano Convention", note 264.

${ }^{299}$ Ibid. see Section 19.

300 "Privacy and Injunctions", note 43, para. 72. See also, "Privacy Injunctions Unsustainable, says Cameron". BBC website, 23 May 2011. Available at: <http://www.bbc.co.uk/news/uk-13498504>[Accessed 1 July 2016].

301 "Privacy and Injunctions", note 43, para. 74.

302 "CTB v News Group Newspapers Ltd”, note 51.

303 Sunday Herald (Scottish Newspaper, 22 May 2011 Edition). Available at: <http://www.webdoodles.org/webimages/sundayherald22may2011.jpg> [Accessed 1 July 2016].

${ }^{304} I d$. See also, Adam Gabbatt and Matthew Taylor, Scottish Newspaper Identifies Injunction Footballer (The Guardian, 22 May 2011).

${ }^{305}$ Sunday Herald Names Footballer Accused on Twitter. BBC website, 22 May 2011. Available at: <http://www.bbc.co.uk/news/uk-13491086> [Accessed 1 July 2016].

306 "Privacy and Injunctions", note 43, para. 71.

${ }^{307}$ Regina v. Connor and another (Appellants) (On Appeal from the Court of Appeal (Criminal Division)). Regina v. Mirza (Appellant) (On Appeal from the Court of Appeal (Criminal Division)) (Conjoined Appeals) [2004] UKHL 2, para. 16.

${ }^{308}$ Chapter 49.

${ }^{309} 1$ William \& Mary Sess. 2 c 2.

${ }^{310}$ Malcolm Jack, Mark Hutton, Christopher Johnson, Douglas Millar, Simon Patrick, Alan Sandall (Eds) Parliamentary Practice (Eds.) (Erskine May: Butterworths Law, 23rd Revised Edn., 2004) at 78.

${ }^{311}$ Ibid. at 95 .

${ }^{312}$ Stockdale v Hansard (1839) 9 Ad \& E 1, at 147-148, per Lord Denman CJ, stating that where the subject matter falls within their jurisdiction, without doubt we cannot question their judgment.

${ }^{313}$ R v Chaytor \& Others [2010] 3 WLR 1707, para. 13.

${ }^{314}$ Pepper v Hart [1993] AC 593 at 638. Note that Lord Browne-Wilkinson made a similar observation when giving the judgment of the Judicial Committee of the Privy Council in Prebble v Television New Zealand Ltd [1995] 1 AC 321 at 334.

${ }^{315} \mathrm{Ibid}$. para. 28, observing that the primary object of the article was unquestionably to protect freedom of speech in the House of Commons.

${ }_{316}$ Bradlaugh v Gossett (1884) 12 QBD 271, at 275, per Lord Coleridge CJ.

${ }^{317}$ Ex parte Wason (1869) LR 4 QB 573, at 576 per Cockburn CJ, 'a conspiracy to make such statements would not make the persons guilty of it amenable to the criminal law'.

${ }^{318}$ Buchanan v Jennings (Attorney General of New Zealand intervening) [2005] 1 AC 115, para. 17, per Lord Bingham. 
Is Social Media Challenging the Authority of the Judiciary? Rethinking the Effectiveness of Anonymised and Super Injunctions in the Age of the Internet

319 A. v. the United Kingdom [2003] 36 EHHR 51, para. 21, reasoning that the words spoken by MPs in the course of debates in the House of Commons are protected by absolute privilege.

${ }^{320}$ Ibid. "Pepper v Hart", note 311 at 624 D.

${ }^{321}$ Hansard, HC Deb 23 May 2011, col 638.

${ }^{322} \mathrm{Id}$.

${ }^{323}$ Dan Sabbagh and Josh Halliday, Injunction Remains Despite MP's Revelation (The Guardian, 23 May 2011).

${ }^{324} I d$.

${ }^{325}$ John Plunkett, Imogen Thomas "Vindicated' after Footballer Drops Blackmail Claim" (The Guardian 15 December 2011).

${ }^{326}$ Chapter 93 and 4 Vict.

${ }^{327} \mathrm{Id}$.

328 Joint Committee on Parliamentary Privilege (House of Lords and the House of Commons, HL 43-I / HC 214-I, Session 1998-1999) at 204.

${ }^{329}$ Ibid. Glancy, note 67.

${ }^{330}$ Danielle Keats Citron, “Cyber Civil Rights” (2009) 89 Boston University Law Review 1, 61 at 89 .

331 "Privacy and Injunctions", note 43, para. 92.

332 Ibid. at para. 93.

${ }^{333}$ Patricia Sanchez Abril, “A (My)Space of One's Own: On Privacy and Online Social Networks" (2007) 6 Northwestern Journal of Technology and Intellectual Property 1, 73 at 75 , para. 8.

334 "Privacy and Injunctions", note 43, para. 97.

${ }^{335}$ The Huffington Post. Available at: <http://www.huffingtonpost.co.uk/entry/injunctioncelebrity-world-famous-marriage-who-had-an-affair_uk_570a5831e4b0fa55639d3842> [Accessed 12 September 2016]. 